University of San Diego

Digital USD

Theses

Theses and Dissertations

Spring 4-20-2021

\title{
Historical Ecology of the San Diego Sport Fishery: Catch Composition, Species Trends, and Fishing Effort from 1959 to 2011
}

Rebecca Schwartz Lesberg

University of San Diego

Follow this and additional works at: https://digital.sandiego.edu/theses

Part of the Marine Biology Commons, and the Other Ecology and Evolutionary Biology Commons

\section{Digital USD Citation}

Schwartz Lesberg, Rebecca, "Historical Ecology of the San Diego Sport Fishery: Catch Composition, Species Trends, and Fishing Effort from 1959 to 2011" (2021). Theses. 52.

https://digital.sandiego.edu/theses/52

This Thesis: Open Access is brought to you for free and open access by the Theses and Dissertations at Digital USD. It has been accepted for inclusion in Theses by an authorized administrator of Digital USD. For more information, please contact digital@sandiego.edu. 


\title{
UNIVERSITY OF SAN DIEGO
}

\author{
San Diego
}

Historical ecology of the San Diego sport fishery:

Catch composition, species trends, and fishing effort from 1959 to 2011

A thesis submitted in partial satisfaction of the

requirements for the degree of

Master of Science in Marine Science

by

Rebecca Schwartz Lesberg

Thesis Committee

Drew Talley, Ph.D., Chair

Theresa Sinicrope Talley, Ph.D.

Matthew Craig, Ph.D. 
The thesis of Rebecca Schwartz Lesberg is approved by:

Drew Talley, Ph.D., Chair

Theresa Sinicrope Talley, Ph.D.

Matthew Craig, Ph.D.

University of San Diego

San Diego

2021 
Copyright 2021 Rebecca Schwartz Lesberg 


\section{DEDICATION}

This thesis is dedicated to anyone whose path to reaching their goals has been markedly non-linear. 


\title{
ACKNOWLEDGMENTS
}

The author would like to thank the following people and organizations for their support in the completion of this thesis:

\author{
Funders/Organizational Support \\ University of San Diego College of Arts and Sciences \\ University of San Diego Department of Environmental and Ocean Sciences \\ University of San Diego Trans Border Institute \\ University of San Diego Copley Library \\ San Diego Central Library \\ Ocean Discovery Institute
}

$\underline{\text { Science Support }}$

Dr. Drew Talley

Dr. Theresa Sinicrope Talley

Dr. Matthew Craig

Dr. Ron Kauffman

Dr. Dovi Kacev

Dr. Whitney Friedman

Professional Support

AMEC Foster Wheeler/Busby Biological - Melissa Busby

Audubon California - Juan Altamirano, Casey Arndt, Andrea Jones, Mike Lynes 
Catalina Island Marine Institute - Paul Kupferman

San Diego Audubon Society - Chris Redfern, Jim Peugh

\author{
Personal Support: \\ Anne and Jim Statler \\ Ross and Lannette Schwartz \\ Stephen and Naomi Lesberg \\ Jaclyn Schwartz Jennings
}

And last, but never least:

Bennett Lesberg 


\section{TABLE OF CONTENTS}

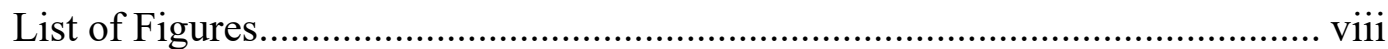

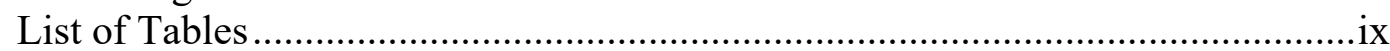

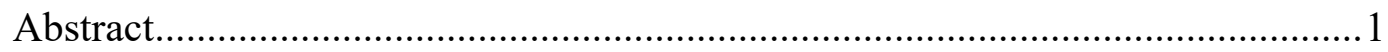

Chapter 1 - Background ............................................................................... 2

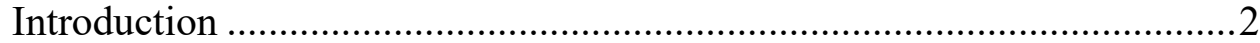

Sportfishing in San Diego: A brief history .............................................2

Shifting baselines and the need for historical data ................................... 3

Impacts of fishing on fish populations: A brief review ............................ 6

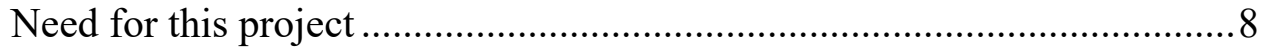

Chapter 2 - Historical ecology of the San Diego sport fishery: Catch composition,

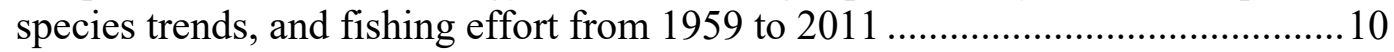

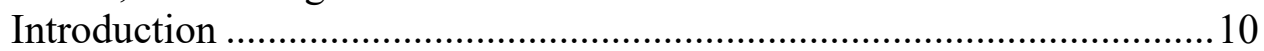

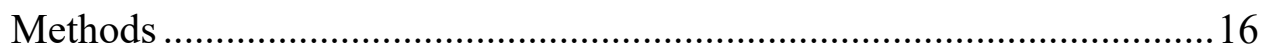

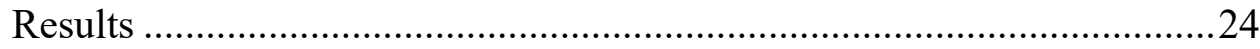

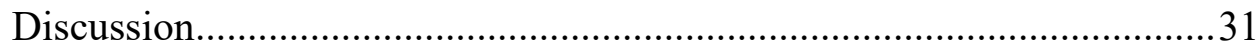

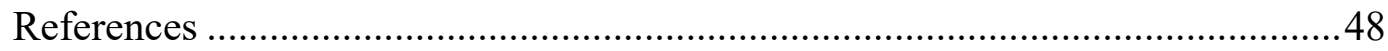

Appendix A: Catch and CPUE for all 21 focal species.....................................53 


\section{List of Figures}

Figure 1: Catch, effort, and CPUE of the San Diego CPFV fishery 1959-2011 ...24

Figure 2: CPUE through time for eleven example species................................26

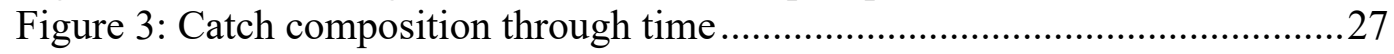

Figure 4: nMDS plot of catch composition through time ..................................28 


\section{List of Tables}

Table 1: Focal species/genera used in CPUE analysis .......................................21 Table 2: Mean and Standard Deviation of Catch, Effort, and CPUE through time 25

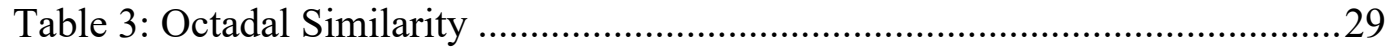

Table 4: CPUE and Oceanographic Conditions ............................................ 30 


\begin{abstract}
Like ocean systems around the world, species targeted by the San Diego sportfishery are subject to myriad threats from human activity, with several species already showing documented decline. However, long-term fisheries datasets are often lacking, limiting natural resource managers' ability to appropriately manage these ecologically and economically important species. Therefore, this study used daily reports published in two Southern California newspapers to examine changes in catch composition, effort, and catch per unit effort (CPUE) from 1959-2011 for the San Diego commercial passenger fishing vessel (CPFV) sportfishery. This study then tested the relationship between those patterns and three large scale oceanographic conditions to provide insights into potential drivers of change. During the study period, composition of landings changed from being dominated by relatively few species in the 1960s and 1970s to a richer, and different, composition in the 1990s through 2010s. No species displayed a trend of increasing CPUE, while CPUE for several species (Bonito, Barracuda, and Mackerel) decreased across the study period and changes in largescale oceanographic conditions alone did not explain the change. Despite the popularity of California Halibut in the sportfishing community, its CPUE appears to have stabilized at low levels, potentially making it an example of a shifting baseline. Meanwhile, Sebastes spp were strongly associated with cold water, suggesting it may be prudent to model expected responses of species within this genus to changing ocean temperatures associated with global climate change. The State of California has and will continue to invest in the management of its coastal marine resources. These actions will be both more effective and more costefficient when based on the best available information regarding the populations and habitats it seeks to protect. As this study has shown, analysis of CPFV landings, combined with oceanographic data and information on management and angler preferences, can provide an important tool to help understand what is happening in the populations of popular sportfishing species.
\end{abstract}




\section{Chapter 1 - Background}

\section{$\underline{\text { Introduction }}$}

Recreational fisheries of Southern California, and San Diego in particular, are an important part of the region's economy and heritage. Over the past century, abundance and composition of these fisheries have fluctuated, due in part to myriad natural and anthropogenic stresses associated with the nearshore environment off a semi-arid and highly urbanized region. Understanding longterm community-level shifts in catch and insights into the drivers underlying those shifts are needed to better manage these fisheries, especially in the face of climate change. In addition to the economic and social values of recreational fishing, this industry has generated long-term catch datasets that, in some cases, are the best available data we have for evaluating community level shifts over long time scales. While catch data have limitations, such as the potential inability to untangle individual driving factors, the long-term nature of this dataset allows assessments of the influences of large temporal-scale oceanographic processes and management changes, and reduces biases associated with shifting baselines.

\section{Sportfishing in San Diego: A brief history}

Understanding changes in the recreational fisheries in the San Diego region is of particular interest because of the value of fishing to the economy and the heritage of the region. In the early $20^{\text {th }}$ century, San Diego gained considerable notoriety as a destination for "rod and reel" sportfishing, attracting thousands of 
recreational anglers each year (Palmer 1912). Commercial fishing in San Diego in the early part of the $20^{\text {th }}$ century focused primarily on Albacore rather than other tuna species (Felando and Medina 2012) in part to avoid competition with the area's game fishing industry, which focused heavily on Bluefin Tuna (Palmer 1912). Today, recreational fishing contributes more than $\$ 4.6$ billion to California's economic output (Southwick 2017) with two thirds of the state's marine fishing occurring between San Diego and Santa Barbara (Southwick 2009).

The commercial passenger fishing vessel (CPFV) industry has operated in southern California waters since at least the early 1900s, and in its early years was mostly the purview of a wealthy few (Young 1969). In the 1920s and 1930s, the CPFV fleet expanded considerably and by the mid-1950s boats were venturing into Mexican waters, targeting Yellowtail, White Seabass, Pacific Barracuda, billfish, and tuna species (Holts 1985). As the size, speed, and comfort of the CPFV boats increased during this time, boats were more easily able to target the Channel Islands, offshore banks, and the Coronado Islands (Holts 1985). Today, San Diego is often referred to as the "Saltwater Sportfishing Capital" of the western United States (Haugen 1990).

\section{Shifting baselines and the need for historical data}

Scientific studies are typically conducted over short time scales (less than ten years) and may be unlikely to detect patterns of ecological change associated with 
long-term processes (Jackson 1997). This situation is exacerbated by the phenomenon known as shifting baselines (Pauly 1995, Dayton et al. 1998), which describes how science and society gradually become adjusted to changing systems. If an accurate baseline is known for a given system, it allows for the establishment of meaningful targets for restoration and conservation efforts. However, the acceptance of a shifted baseline as "normal" is often the case because some of the largest changes to natural systems (e.g., population declines, habitat shifts) often happened before scientific data were collected regularly (Olsen 2002), and evidence of such changes may be available only in the form of anecdotes or historical data (Pauly 1995, Swetnam et al. 1999, Jackson et al. 2001). In the case of fisheries management, management schemes are often implemented after industrialized and/or intense recreational fishing has begun, and thus can serve to stabilize fish biomass at artificially low levels relative to true historic conditions (Myers and Worm 2003).

One way to mitigate the effects of shifting baselines is through the use of relatively longer-term studies, which (due to the rarity of long-term data sets) can require the use of historical data, often from non-traditional sources including photographs, logbook entries, newspaper reports, etc (e.g., Jackson et al. 2001, McClenachan 2009, Bellquist et al. 2016). These sources can include quantitative, systematically collected historical data, which can provide indications of longterm changes where traditional data do not exist. While use of these types of data prohibits the construction of a randomized experimental design, and the method 
of collection and quality may vary, it does not prevent the use of this information for scientific inquiry.

Numerous studies have successfully highlighted the strength and validity of historical data in rigorous ecological examinations (Jackson et al. 2001, Pitcher 2001, Sala et al. 2004, Saenz-Arroyo et al. 2005, McClenachan 2009, Bellquist et al. 2016, Fortibuoni et al. 2017), including specifically using information from captains' logs from commercial passenger fishing vessels in California to document, quantify, and analyze changes in fisheries targeted by recreational anglers (e.g., Dotson and Charter 2003, Erisman et al. 2011). However, this approach does affect the kinds of questions that can be asked and the way conclusions are framed. Despite potential shortcomings, historical data provide a window into past ecosystem conditions that otherwise may be unavailable to the modern investigator.

In the case of fisheries, it is important to note that landings data and other fisheries-dependent information come with their own suite of limitations (Bishop 2006). A particularly relevant limitation is the ability of fisheries-dependent data to mask hyperstability (wherein true abundance declines despite stable CPUE) in fisheries that target spawning aggregations, as has been demonstrated for key target species of the CPFV fishery in San Diego (Erisman et al. 2011). Therefore, information from these data must be combined with stock-assessments using fisheries-independent data sources to inform fisheries management strategies. 
Nonetheless, historic landings data can offer an otherwise unavailable window into past conditions for species heavily targeted by the CPFV fleet in San Diego. Specifically, these data are able to provide information regarding trends in species composition and CPUE through time, as well as their potential association with large-scale oceanographic conditions that occur over long time scales (e.g., Pacific decadal oscillations).

\section{Impacts of fishing on fish populations: A brief review}

Anthropogenic disturbances to the world's oceans are numerous, and include global climate change, habitat destruction, pollution/contamination, and fishing pressure (Bruland et al.1974, Zedler 1991, Dotson and Charter 2003, Gruber et al. 2012), with most documented impacts beginning in the late twentieth and early twenty-first centuries (Jackson et al. 2001). Because the current study uses data from the fishing industry to identify trends in species specifically targeted by sportfishing activities, the suite of possible impacts of fishing on fish populations is briefly reviewed here. Non-fisheries drivers of changes in fisheries composition and abundance (e.g., changes in angler preference, oceanographic conditions, etc.) are discussed in Chapter 2.

Fishing can provide social and economic benefits (Pollnac and Poggie 2008, Southwick 2017) and in some cases may even benefit fish communities, for example by enhancing prey diversity and abundance through (mild) geardisturbance, modulation of competitor species through a reduction in the 
availability of prey (target species), and productivity inputs to ecosystems through bycatch discards (Martinez-Abrain et al. 2002, Gribble 2003, Zhou 2008, van Denderen et al. 2013). Despite these benefits, overfishing is often the reported cause of fisheries declines worldwide, perhaps because fishing has had direct effects on fisheries for longer than other widespread anthropogenic stressors (Jackson et al. 2001) and has the potential to seriously impact marine fisheries and their environments (Great Britain Royal Commission on Trawling 1885, Tegner and Dayton 2000, Jackson et al. 2001, Worm et al. 2006, Pauly et al. 1998, Pauly and Zeller 2016).

In general, the majority of overfishing and its impacts have been attributed to industrial-scale fishing and to commercial fishing in general as opposed to recreational fishing, since the former have the capacity to capture far more individuals per unit time. Data reveal, however, that recreational fishing can also have substantial and lasting effects on fish populations (e.g., Schroeder and Love 2002, Coleman et al. 2004, McClenachan 2009). This occurs through intensive capture in a relatively small area, capture of sensitive life stages/activities (e.g., mating, spawning, juvenile, largest/most fecund individuals) (Cooke and Gowx 2004), and/or catch-and-release mortality, which has been documented across taxa in geographically distinct systems and is especially pronounced in larger individuals with longer fight times (Millard et al. 2003, Heberer et al. 2010). Barotrauma, despite recompression efforts, remains a cause of catch and release mortality in Sebastes species, a popular target of the San Diego sportfishery, 
including protected rockfish species whose stock relies heavily on mandatory fish release (Parker et al. 2006, Jarvis and Lowe 2008, Pribyl et al. 2012, Rankin et al. 2017, Bellquist et al. 2019). Additionally, recreational fishing can have a negative effect on often sensitive nearshore habitats themselves (Halpern et al. 2003) through noise, wake, and pollution associated with increased boat traffic and discarded fishing gear (hooks, line, lead weights) (Arlinghaus and Cooke 2009, Cowx 2002, McPhee et al. 2002).

The effects of fishing pressure on stocks depends in large part upon appropriate, science-based management that keeps current with changing conditions (Hilborn and Ovando 2014). Fisheries declines can occur in cases of uninformed, poor, or no management, and often when high fishing pressure occurs in concert with one or more other stressors (Jackson 2001, Valero and Waterhouse 2016, Santora et al. 2017). Effective and responsible fisheries management in turn requires scientific assessment of stocks, including an understanding of basic fishery biology, such as stock sizes, distributions, and maximum sustainable yield (MSY). Also needed is an understanding of relationships between fish stocks and long-term environmental fluctuations, such as climate change impacts and El Niño/Southern Oscillation (ENSO) events.

\section{Need for this project}

Previous studies (e.g., Dotson and Charter 2003) used newspaper reports of landings from the California sportfishery to begin investigating long term trends 
in fisheries targeted by CPFVs. However, there is need to expand the timeframe of investigation with additional years of data, as well as focus more closely on the San Diego sportfishery itself to investigate potential explanatory variables for patterns that emerge. The goal of this study was, therefore, to conduct a detailed examination of patterns in CPFV recreational fish stocks in San Diego over an extended time period, test the relationship between those patterns and a suite of environmental factors, and gain insight into possible fishery-independent controls on stocks. 


\section{Chapter 2 - Historical ecology of the San Diego sport fishery: Catch composition, species trends, and fishing effort from 1959 to 2011}

$\underline{\text { Introduction }}$

Recreational fishing in southern California

Recreational fishing contributes more than $\$ 4.6$ billion to California's annual economic output (Southwick 2017), with two thirds of the state's marine fishing occurring between San Diego and Santa Barbara (Southwick 2009). In addition to the economic benefits of sportfishing, the sport provides social benefits including connecting people to nature, food provision, and recreation (Pollnac and Poggie 2008). Recreational fishing is particularly important in San Diego, known as the "Saltwater Sportfishing Capital" of the western United States (Haugen 1990), which has a commercial passenger fishing vessel (CPFV) fleet dating back to at least the early 1900s (Young 1969). In addition to shore-based and private boat recreational fishing, the large CPFV fleet operates out of four major landings based in Mission Bay and San Diego Bay (Parnell et al. 2010). Each chartered vessel typically carries between 30-50 anglers on half day, full day, overnight, twilight, and multi-day trips. While the overnight and multi-day trips visit offshore destinations (e.g., the Coronado Islands), most half day and full day trips remain nearshore, particularly in the kelp beds off Point Loma and La Jolla (Parnell et al. 2010). 
Like ocean ecosystems around the world, the southern California nearshore environment is subject to myriad threats from anthropogenic activities, including pollution, habitat destruction, climate change, and fishing pressure (Bruland et al. 1974, Zedler 1991, Jackson et al. 2001, Dotson and Charter 2003, Gruber et al. 2012). While commercial fishing removes more individuals per unit time, often resulting in stronger ecosystem consequences than recreational fishing, data suggest recreational fishing can also have substantial, negative, and lasting effects on fish populations (e.g., Schroeder and Love 2002, Coleman et al. 2004, McClenachan 2009). However, there are many stressors influencing fish stocks (natural and anthropogenic, fishery-dependent and fishery-independent, acute and longer-term) and the effects of fishing pressure on stocks depend in large part upon appropriate, science-based management (Hilborn and Ovando 2014). Effective and responsible fisheries management in turn requires scientific assessment of stocks, including an understanding of relationships between fish stocks and long-term environmental fluctuations.

Several San Diego fisheries have experienced fluctuations and/or reductions in catch per unit effort that suggest possible changes in the fish populations through time (Limbaugh 1955, Jarvis et al. 2004, Miller and Erisman 2014, Valero and Waterhouse 2016). Of particular interest are fishes of economic importance, which not only contribute to the regional economy, but also encompass a variety of ecologically important functional groups. Understanding the patterns of change in fishery species and the relationship of these patterns to possible drivers (fishing 
pressure, large-scale oceanographic conditions, and changing fishing regulations, including the implementation of marine protected areas) is needed to ensure effective management of these ecologically, economically, and socially important fisheries. This is especially true as the stresses associated with climate change intensify (Chavez et al. 2017).

\section{Use of fishery catch data}

Long-term fisheries biological datasets, often lacking due to the challenges associated with assessing population or stock sizes of species that cannot be easily observed, are another value of recreational fishing. Since 1936, the California Department of Fish and Wildlife (formerly California Department of Fish and Game) has required CPFV operators to report catch by species and the number of anglers onboard (Holts 1985). Starting in the early 1950s, these reports were published in several southern California newspapers, including the Los Angeles Times and the San Diego Union Tribune. Subsets of these data have been used to better understand changes in taxonomic representation, catch per unit effort (CPUE), total catch, and total effort through time for the California sportfishery, including San Diego (Dotson and Charter 2003). A previous study (Dotson and Charter 2003) analyzed data from 1959 through 1998 across California broadly but did not attempt to explain the patterns that emerged. Therefore, this updated analysis encompassed additional years of data, focusing specifically on the San Diego region, and investigated potential drivers of fisheries change. 


\section{Drivers of change in fisheries catch data}

Fisheries catch data are not a direct approximation of population or stock sizes because they are also influenced by social and fishery-independent environmental drivers, such as species abundances, environmental conditions, management strategies, technological abilities, and social preferences (Pauly et al. 2013). In San Diego, catch data are likely influenced by changing preferences among anglers (Edwards 1992), changes in management strategies (Yoklavich et al. 2007), and fluctuations in large scale oceanographic conditions (Perry et al. 2005).

1. Angler preferences: Changes in preference through time may relate to changing demographics among the angling community, which may mirror changing demographics in the local community. For most of the history of the CPFV fleet, most anglers were relatively wealthy and were predominantly white males (Dewees et al. 1990). Throughout the $20^{\text {th }}$ century, however, many of the wealthier anglers shifted to private boats and charters (Dewees et al. 1990), with the composition of CPFV clients potentially shifting to include a higher proportion of minority communities. With shifts in race and ethnicity, likely came shifts in preferences for target species (e.g., Mintz and DuBois 2002, Moya 2004). Changing fishermen's preference may also simply be a matter of social trends, including the community's impression of the health value and safety of certain species (Edwards 1992, Burger and Gochfeld 2009, Carroll 2016) as well as the impact of popular culture 
on consumer choice (Bestor 2000, Leschin-Hoar 2014). Finally, what may appear as a change in preference may actually be the result of improvements in fishing technology, particularly the increased availability of fish tracking technology or "fish finders" (Burden 2019). This change may appear in fisheries landings, such as an increase in highly migratory species (e.g., billfishes, tunas) as anglers are able to target species other than those likely to appear in predictable aggregations (e.g., spawning aggregations).

2. Fisheries management: Changes in management regimes can impact the composition of species in CPFV landings. In general, management rules fall into three broad categories:

a. Species-specific regulations (e.g., size limits; California's 1981 ban on commercial and recreational fishing of giant sea bass [Stereolepis gigas; Crooke 1992])

b. Gear restrictions (e.g., California's requirement that finfish only be taken using hook-and-line or by hand, with few exceptions [CDFW 2021])

c. Area closures (e.g., the enactment of California's Marine Life Protection Act of 1999, which enabled the creation of a system of marine reserves with various levels of fishing restrictions along the California coast [Kirlin et al. 2013])

In certain cases, species-specific management actions (particularly those that involve regional restrictions on fishing activity) have the 
ability to protect a suite of species, which may thereby impact the frequency of their occurrence in fisheries catch. For example, in response to declines of Cowcod (Sebastes levis) resulting from overfishing (Butler et al. 1999), the Pacific Fisheries Management Council established two Cowcod Conservation Areas in 2001 where fishing for groundfish is prohibited at certain depths (Yoklavich et al. 2007). Not only has this limited anglers' ability to target Cowcod, but it has indirectly protected 50 additional species of rockfishes, as evidenced by increases in the larvae of several rockfish species (Thompson et al. 2017).

3. Oceanographic conditions: Large-scale oceanographic conditions including the El Niño/Southern Oscillation (ENSO), the Pacific Decadal Oscillation (PDO), and increasing ocean temperatures associated with climate change have the potential to drive changes in total population, species range, age structure, and other population dynamics (Lane 1965, Squire 1983, Perry et al. 2005). Because these conditions occur over long time scales, identifying their impact on fish populations requires long-term data sets that offer a window into historic conditions of focal species.

\section{Project goal}

Given the economic and social importance of recreational fishing in San Diego, and the myriad factors affecting catch data, a better understanding is needed of the 
long-term changes in recreational fishing catch, with insights into factors influencing those fluctuation, to inform fisheries management. The goal of this project, therefore, was to conduct a detailed examination of patterns in recreational fish stocks over an extended time period, test the relationship between those patterns and a suite of environmental factors, and gain insight into fishery-independent controls on stocks.

\section{Methods}

This study used daily catch and effort data from the San Diego CPFV fleet as reported in two local southern California newspapers, the San Diego Union Tribune (UT) and the Los Angeles Times (LAT), covering the period 1959-2011. Data for the period 1959-2003 were from an online database of LAT reports maintained by the National Marine Fisheries Service. Data for the period 20042011 were digitized by this project directly from UT microfilm (data from 20042011 were not available from the LAT as this newspaper stopped publishing Daily Ocean Fishing reports in 2003). Both newspapers sourced data directly from the same landings of the CPFV fleet in San Diego and previous studies (e.g., Erisman et al. 2011) similarly used CPFV data from two sources as one continuous database, as was done in this study. This resulted in a digital dataset from 1959-2011 with daily information regarding catch (broken down as the number of individuals per species/taxonomic group) as well as effort (including number of anglers and number of boats) for each San Diego CPFV landing. Fish reported as "released" were not included. 
During this period, 147 taxonomic groups (usually species, but see note regarding Sebastes and Paralabrax genera) were reported. Usually, these groups were reported as a single species by common name, for instance Yellowtail (Seriola dorsalis), Bonito (Sarda chiliensis), and Pacific Mackerel (Scomber japonicus). Where possible each of the reported common names was assigned to a single scientific name, including in the cases of multiple common names as with Dorado/Dolphinfish (Coryphaena hippurus). However, there were two notable exceptions:

1. Rockfishes (Sebastes spp.) were rarely identified as individual species (e.g., Salmon Grouper/Bocaccio), and were more frequently combined as "rockfish", "rock cod", "red rock fish", "reds", "red rock cod", and "vermillion rock fish". Though previous analysis of these data (Dotson and Charter 2003) suggested "rock cod" and "rock fish" may represent deep and shallow Sebastes species respectively, the current study does not assume such a distinction. When digitizing the data, the various names given to groups/sub-groups of Sebastes were included as reported. However, all designations for Sebastes were combined into one group for analysis due to low confidence in meaningful distinction between them. Therefore, this dataset is not a robust source for analyzing changes in particular Sebastes species through time, but only general trends in the genus.

2. Fishes from the genus Paralabrax were variously identified to species (e.g., Kelp Bass/P. clathratus, Barred Sand Bass/P. nebulifer), or to 
the group "bass". Again, these names were included as reported during the digitization of data but were combined into Paralabrax spp. for analysis. This was done primarily to maintain consistency with previous analyses of this dataset (e.g., Dotson and Charter 2003), which similarly combined the three Paralabrax species into one genus for analysis. Like with Sebastes, this grouping obfuscates potential patterns in the individual Paralabrax species that have been reported elsewhere (e.g., Erisman et al. 2011, Miller and Erisman 2014).

Because most designations in the dataset refer to a single species (rather than a genus as with Sebastes and Paralabrax), the term "species" is used in a description of the analysis and results below, even when referring to what are technically genera in the cases of Sebastes and Paralabrax.

\section{Analyses}

Daily catch and effort values were summed across landings and trip lengths to create one value of daily total effort and daily total catch per species, which was further summed to create monthly and annual total catch and effort values used in analyses described below. While previous studies (e.g., Dotson and Charter 2003) examined raw catch data, this study standardized catch into catch per unit effort to overcome seasonal bias within the data (i.e., higher effort during spring/summer). In this case, effort was identified as "angler-trip" and no distinction was made for various trip lengths. (Note: had effort been identified as "boat-trip" rather than 
"angler-trip", the results would likely have emphasized the effects of larger party boats, which tend to stay closer to shore. Had effort been defined as "angler-day", separating out half, three-quarter, and full-day boat trips, it would likely have underemphasized the longer trips that target offshore species. Additionally, using “angler-trip" maintains consistency between this study and previous studies using similar datasets and methodologies.)

Changes in catch composition over time were examined using multivariate statistical analyses in which the averaged annual CPUE abundance data were grouped into (used as replicates in) seven broad, 8-yr (octadal) time periods: 1959-1966, 1967-1974, 1975-1982, 1983-1990, 1991-1998, 1999-2006, $2007-$ 2011. These 8-yr intervals were chosen to reduce the effects of autocorrelation of the longer-lived species targeted by this fishery. The octadal time period groupings were chosen based on the result that the highest incidence (86\%) of community composition differences occurred between 8-yr time periods (all but one pair of concurrent octades differed from each other; ANOSIM $p \leq 0.05$ ). Composition between time periods within the shorter intervals $(2,3,4,5,6$ and 7 yr intervals) and longer intervals (9, 10 and $11 \mathrm{yr}$ intervals) differed less frequently than between the 8 -yr time periods (only $0-60 \%$ of all pairwise comparisons within other time intervals were significantly different; ANOSIM $\mathrm{p} \leq 0.05)$ 
Analysis of the summed and standardized data was conducted in three parts, as follows.

1. Catch, effort, and CPUE through time: Of the 147 species that appeared at least once in the 1959-2011 dataset, many appeared only very rarely (often only once). Therefore, a list of 21 focal species for analysis (Table 1) was established based on taxa meeting any of the following criteria: a) all of the top ten species within any year across entire time series, $b$ ) any species that appeared as $>1 \%$ of the total catch in at least one octade, or c) three additional highly migratory species of interest to fisheries managers (bluefin tuna, bigeye tuna, tuna [unspecified]). These 21 species were then investigated for trends in total catch and CPUE through time.

2. Changes in catch composition through time: The 21 focal species (Table 1) were included for statistical analysis of differences in catch composition between octades. Similarities and differences in catch across octades were visualized using non-metric multidimensional scaling (nMDS; see Clarke 1993) on Bray-Curtis similarity indices of $\log (\mathrm{x}+1)$ transformed, unstandardized CPUE data using R Statistical Platform (R Core Team 2013). For the nMDS analysis, six different random starting points with up to 1,000 steps were used. The stress values from the six runs were examined for stability to determine whether a global solution had been found. 


\begin{tabular}{|c|c|}
\hline \multicolumn{2}{|l|}{$\begin{array}{l}\text { Table 1: Focal species/genera used in CPUE and catch } \\
\text { composition analysis }\end{array}$} \\
\hline Common Name & Scientific Name \\
\hline $\begin{array}{c}\text { Bocaccio } \\
\text { Salmon Grouper) }\end{array}$ & Sebastes paucispinis \\
\hline California Halibut & Paralichthys californicus \\
\hline California Sheephead & Semicossyphus pulcher \\
\hline California Yellowtail & Seriola dorsalis \\
\hline Dorado (dolphinfish) & Coryphaena hippurus \\
\hline Giant (Humboldt) Squid & Dosidicus gigas \\
\hline Kelp/Calico Bass, \\
Sand Bass & Paralabrax spp \\
\hline Lingcod & Ophiodon elongatus \\
\hline Ocean whitefish & Caulolatilus princeps \\
\hline Pacific Barracuda & Sphyraena argentea \\
\hline Pacific Bonito & Sarda chiliensis \\
\hline Pacific Mackerel & Scomber japonicus \\
\hline Rockfish (unspecified) & Sebastes spp \\
\hline $\begin{array}{c}\text { Sculpin (CA } \\
\text { Scorpionfish) }\end{array}$ & Scorpaena guttata \\
\hline Skipjack & Euthynnus pelamis \\
\hline Tuna (unspecified) & Thunnus spp \\
\hline Tuna, Albacore & Thunnus alalunga \\
\hline Tuna, Bigeye & Thunnus obesus \\
\hline Tuna, Bluefin & Thunnus orientalis \\
\hline Tuna, Yellowfin & Thunnus albacares \\
\hline White sea bass & Atractoscion nobilis \\
\hline
\end{tabular}

Table 1: List of 21 focal species/genera (narrowed down from 147 species reported from 1959-2011) for the analysis of change in catch and CPUE from 1959-2011, based on the following criteria: one of the top ten species within any year across entire time series, appeared as $>1 \%$ of the total catch in at least one octade, and was one of three highly migratory species of interest to fisheries managers (Bluefin Tuna, Bigeye Tuna, Tuna [unspecified]).

Stress is a measure of how well the solution (in this case the twodimensional nMDS plots) represents the distances between the data, and only analyses with stress values of $<0.2$ were used. Stress values $<0.1$ are "good" and $<0.2$ are "usable" (Clarke 1993). Significance 
testing for differences in catch composition between octades was completed using an analysis of similarity (ANOSIM; Clark 1993). The significance levels of resultant pairwise comparisons were determined using sequential Bonferroni-adjusted alphas. Analyses of species dissimilarities between time periods, and the particular species contributing to the dissimilarity, were carried out using SIMPER (Clark 1993). The SIMPER results specify which species are responsible for the ANOSIM results by comparing the average abundances of species between groups. The average dissimilarity between samples from the groups is computed and then broken down into contributions from each species. Those species with high average terms relative to the standard deviation are important in the differentiation of groups.

3. Relationships with oceanographic conditions: Using results from the ANOSIM and SIMPER analyses to identify which species were responsible for driving changes between octades, eight species were chosen for investigating the possible relationship between their CPUE and large-scale oceanographic conditions. Three additional economically valuable species were also included. Possible relationships between current and time-lagged oceanographic variables (temperature, PDO, and ENSO) and CPUE (log +1 transformed) were tested with forward, stepwise multiple regressions using JMP Pro 13 Statistical Software. Variables included in the model met the criteria of 
$p \leq 0.05$. Data sources for the oceanographic conditions were as follows:

- ENSO values are as reported from the Oceanic Niño Index, which is the running, 3-month mean sea surface temperature (SST) anomaly for the Niño 3.4 region. Data were accessed via http://www.cpc.noaa.gov/products/analysis_monitoring/ensost uff/ensoyears2011.shtml.

- PDO values are as reported from NOAA's National Centers for Environmental Information (NCEI) index, which is based on NOAA's extended reconstruction of SSTs (ERSST Version 4; Huang et al. 2014). These data were accessed via https://www.ncdc.noaa.gov/teleconnections/pdo/

- Sea surface temperature values are as reported for $\mathrm{La}$ Jolla/Scripps Pier by the Scripps Institution of Oceanography (SIO)'s Shore Stations Program. Data are provided by the Shore Stations Program at SIO and were accessed via https://scripps.ucsd.edu/programs/shorestations/shore-stationsdata/data-sio/ 


\section{$\underline{\text { Results }}$}

Catch, effort, and CPUE through time

Total annual catch (total fish recorded), effort (total annual angler-trips recorded), and catch per unit effort (CPUE; fish per angler-trip) varied from 1959-2011

(Figure 1). However, variability in all three (CPUE, catch, and effort) tended to be lower during the second half of the period compared to the first (Table 2). From 1987 onward, total catch experienced a net decline $\left(r^{2}=-0.43, p=0.032\right)$, even while effort and CPUE generally leveled off during that same period (Figure 1).

Figure 1: Catch, effort, and CPUE of the San Diego CPFV fishery 1959-2011

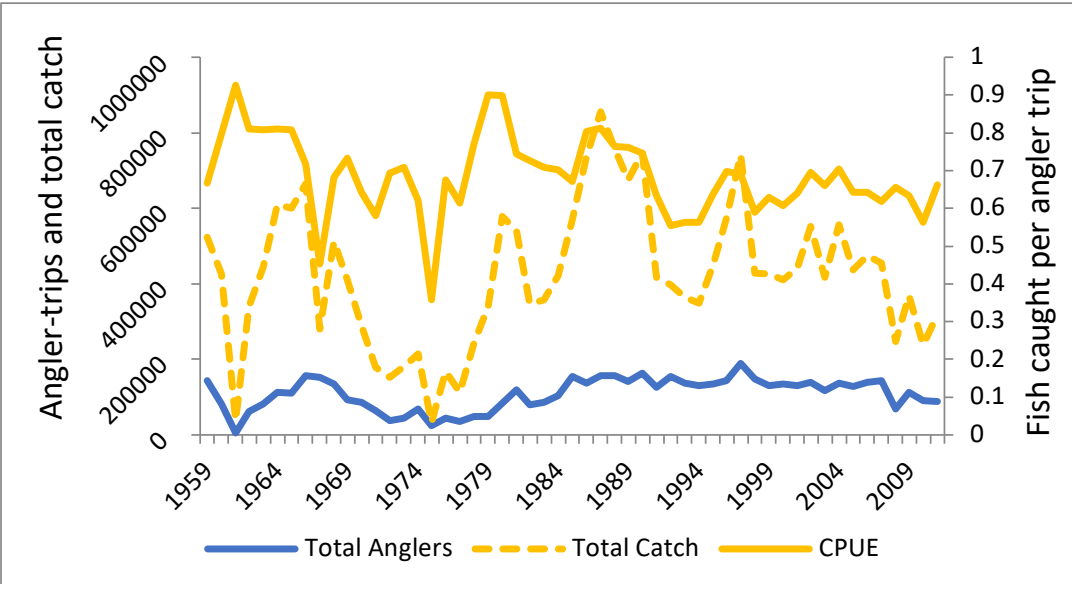

Figure 1: Total catch, effort, and catch per unit effort (CPUE) of the San Diego $C P F V$ fishery through time. Catch is reported as the total number of individual fish reported. Effort is the total angler-trips for that year. CPUE is calculated as the number of fish per angler-trip and has been log +1 transformed. 
Table 2: Mean and Standard Deviation of Catch, Effort, and CPUE through time

\begin{tabular}{|rl|r|r|}
\cline { 3 - 4 } \multicolumn{1}{c|}{} & $1959-1984$ & \multicolumn{1}{c|}{$1985-2011$} \\
\hline Effort & Mean & $\mathbf{8 1 , 3 0 0}$ & $\mathbf{1 3 4 , 8 9 2}$ \\
\cline { 3 - 4 } (angler-trips) & Std. Dev. & 39,980 & 24,353 \\
\hline Catch & Mean & $\mathbf{3 4 6 , 4 8 3}$ & $\mathbf{4 9 6 , 6 2 7}$ \\
\cline { 3 - 4 } (total fish) & Std. Dev. & 180,980 & 163,338 \\
\hline \multirow{2}{*}{ CPUE } & Mean & $\mathbf{0 . 7 1 3 5}$ & $\mathbf{0 . 6 6 0 6}$ \\
\cline { 3 - 4 } & Std. Dev. & 0.1272 & 0.0710 \\
\hline
\end{tabular}

Table 2: Annual mean and standard deviation of effort (total annual angler-trips recorded), total catch (total annual fish recorded), and CPUE (fish per anglertrip) for the period 1959-1984 as compared to 1985-2011.

Of the 21 focal species investigated for trends through time, all displayed variability in both catch and CPUE (Appendix A), with several trends emerging (Figure 2). The CPUE of some species appeared cyclical (e.g., Paralabrax, Sebastes), while others decreased through time (e.g., Bonito, Mackerel, and Barracuda). Several displayed relatively high variability (e.g., Albacore and Yellowtail). Other species peaked early in the dataset and then stabilized relatively low (e.g., Halibut), and several species did not appear in abundance until the second half of the data set (e.g., Dorado, Yellowfin Tuna, and Giant Squid). 
Figure 2: CPUE through time for eleven example species

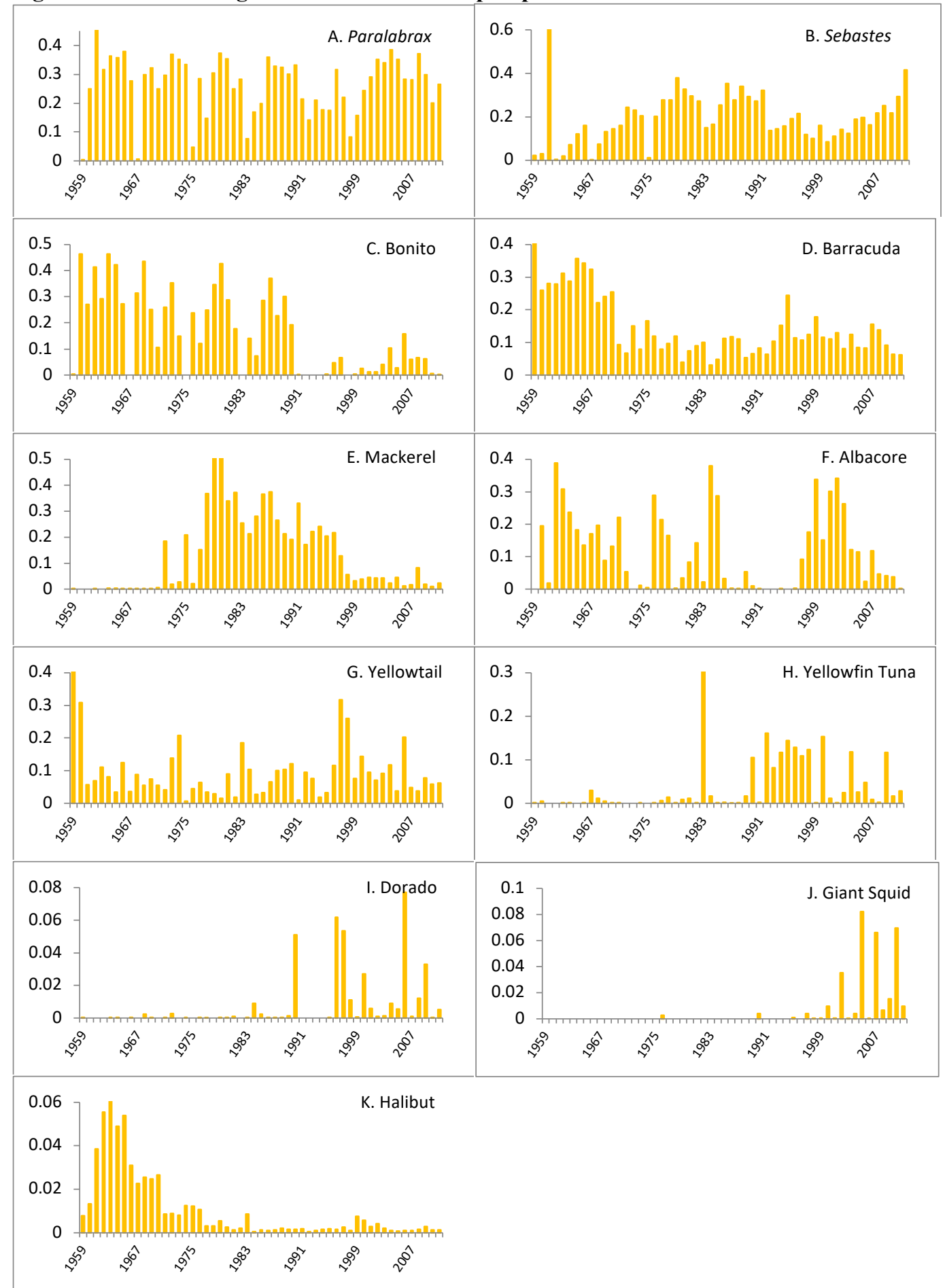

Figure 2: Annual CPUE (log+1 transformed) from 1959-2011 of 11 example focal species investigated for trends in catch and CPUE through time. 


\section{Changes in catch composition through time}

Overall, the diversity of landings (i.e., the number species appearing during various time periods) increased through time $\left(r^{2}=0.82, p<0.01\right.$; Figure 3$)$. The suite of species appearing in the catch during the first three octades (1959-1982) was dominated by seven species that made up over $95 \%$ of the catch, while 11-12 species made up at least $95 \%$ of the catch in the last four octades (1983-2011).

Figure 3: Catch composition through time

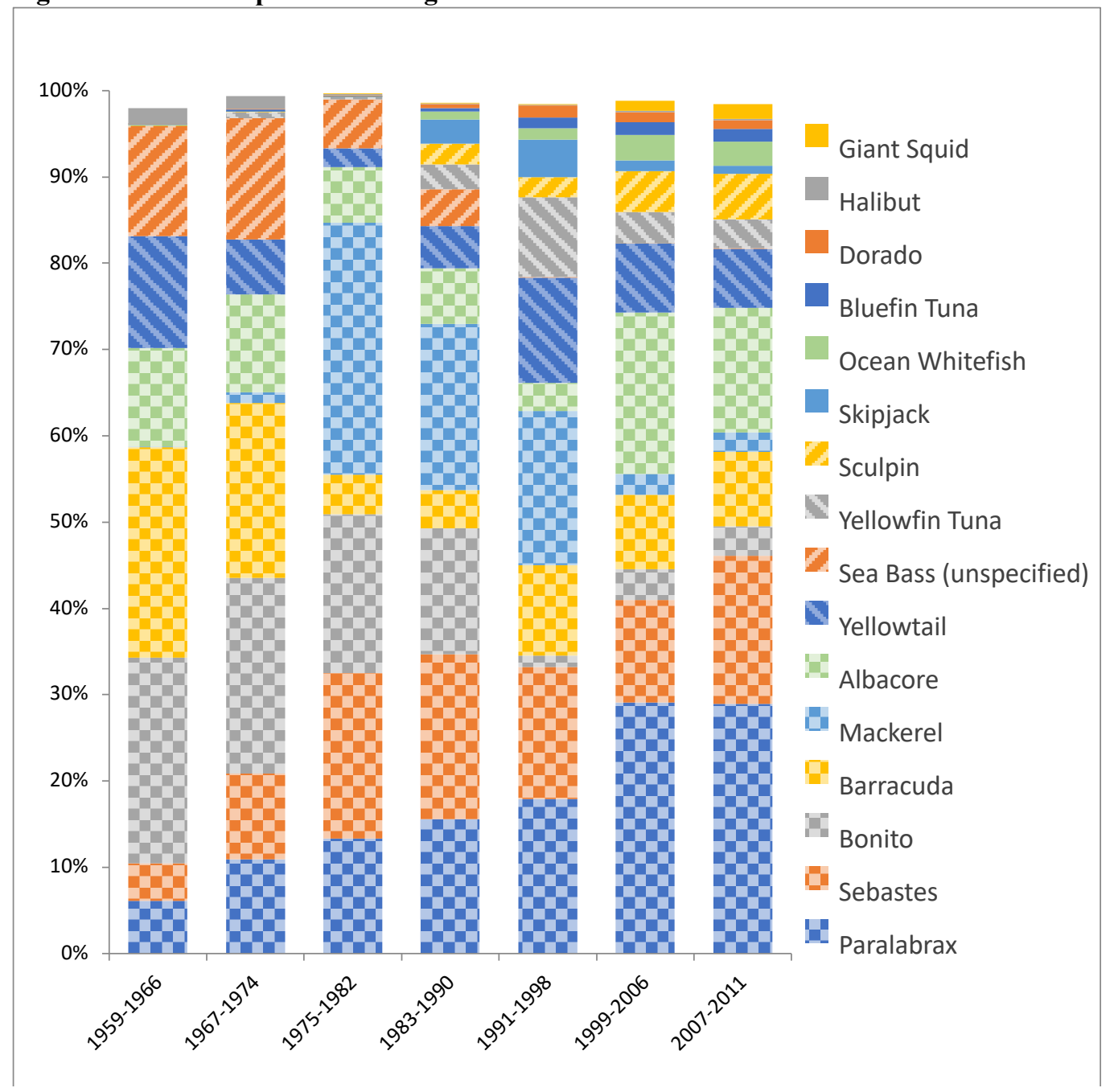

Figure 3: Each species of fish recorded during each octade is displayed as a percentage of total catch for that octade. Because species representing $<1 \%$ of the total catch are not displayed, each octade does not sum to exactly $100 \%$. 
In terms of catch composition, octades tended to be most like their neighboring octade (Figure 4), with two general groups emerging: the late $50 \mathrm{~s}$ - early $80 \mathrm{~s}$ (cooler colors) and the mid80s - early10s (warmer colors).

Figure 4: nMDS plot of catch composition through time

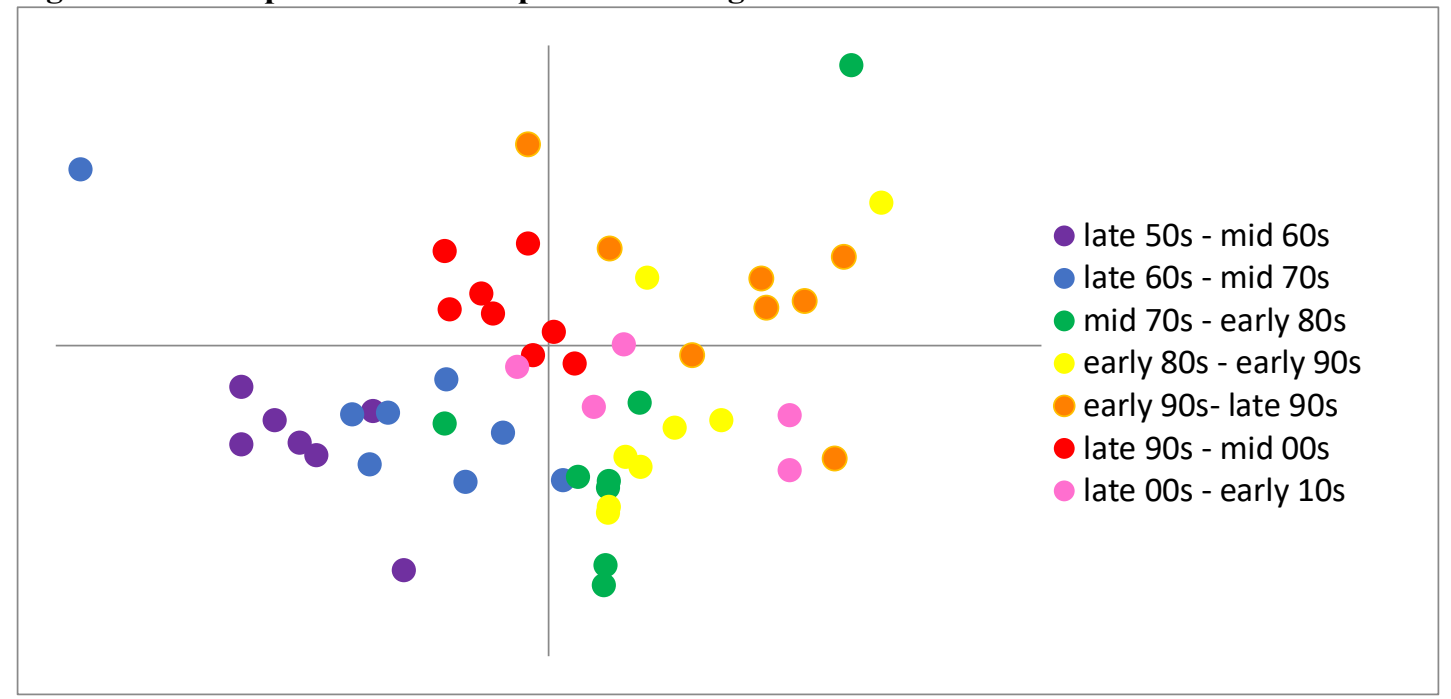

Figure 4: Non-metric multidimensional scaling plot of San Diego CPFV catch composition during each of seven octades from 1959-2011. Stress value $=0.18$.

Overall, each octade tended to be most similar to the octades immediately before/after, with catch composition generally differing more with increasing length of time between octades (Table 3). The main exception to this trend was that the catch composition of the early-90's was the most distinct of any octade. This dissimilarity was driven by generally higher abundances of Yellowtail and Yellowfin Tuna in the early-90s as compared to other octades, and lower abundances of Bonito, Barracuda, Albacore, and Paralabrax. Between the late50s and late-60s (the first two octades), Bonito, Barracuda, Albacore, and 
Paralabrax abundances all decreased, while Sebastes abundance increased. The trend of increased Sebastes abundance, decreased Bonito, Barracuda and Albacore and Paralabrax abundance continued to drive octadal dissimilarity throughout the time series, with fluctuations and generally more minor contributions of six other species. Several species experienced pulses in catch abundance in the middle of this time period (e.g., Mackerel abundance increased from the late-60s to the mid-70s and decreased thereafter). Similarly, Yellowtail and Yellowfin Tuna abundance increased between the mid-70s to early-90s, and decreased again in the final three octades (early-90s through late-00s).

\begin{tabular}{|c|c|c|c|}
\hline \multicolumn{4}{|c|}{ Table 3: Octadal Similarity } \\
\hline Time Periods & $\begin{array}{l}\text { ANOSIM } \\
\text { pairwise } p\end{array}$ & $\begin{array}{l}\text { Dissimilari } \\
\text { ty (\%) }\end{array}$ & $\begin{array}{l}\text { Species contributing }>10 \% \\
\text { of the variability (SIMPER) }\end{array}$ \\
\hline Late $50 \mathrm{~s}$, Late $60 \mathrm{~s}$ & 0.022 & 37.7 & $-\mathrm{BO},+\mathrm{Seb},-\mathrm{B},-\mathrm{A},-\mathrm{Par}$ \\
\hline Late $60 \mathrm{~s}, \mathrm{Mid} 70 \mathrm{~s}$ & 0.003 & 42.74 & $+\mathrm{M},=\mathrm{BO},+\mathrm{Seb},-\mathrm{Par},+\mathrm{A}$ \\
\hline Mid 70s, Early 80s & 0.236 & 35.27 & $-\mathrm{M},-\mathrm{BO},-\mathrm{A},=\mathrm{Par},=\mathrm{Seb},+\mathrm{Y}$ \\
\hline $\begin{array}{l}\text { Early 80s, Early } \\
90 \text { s }\end{array}$ & 0.006 & 40.73 & $\begin{array}{l}\text {-BO, -A, -Par, -Seb, +YT, - } \\
\mathrm{M},+\mathrm{Y}\end{array}$ \\
\hline $\begin{array}{l}\text { Early 90s, Late } \\
90 \text { s }\end{array}$ & 0.001 & 43.42 & $+\mathrm{A},-\mathrm{M},+\mathrm{Par},-\mathrm{Y},-\mathrm{YT},+\mathrm{Seb}$ \\
\hline Late 90 s, Late $00 \mathrm{~s}$ & 0.006 & 32.63 & $\begin{array}{l}\text {-A, +Seb, -Par, -Y, -YT, - } \\
\text { BO, -B }\end{array}$ \\
\hline Late $50 \mathrm{~s}$, Late $00 \mathrm{~s}$ & 0.003 & 57.5 & $-\mathrm{BO},+\mathrm{Seb},-\mathrm{B},-\mathrm{A},-\mathrm{Y},-\mathrm{Par}$ \\
\hline
\end{tabular}

Table 3: Results of ANOSIM and SIMPER analyses for pairwise comparisons of catch composition between temporally adjacent octades. Pairwise $p$ values that are significant compared to sequential Bonferroni adjusted alpha are shown in bold italics. Symbols (+, -, =) indicate whether the species' average abundance increased, decreased or stayed about the same between the earlier and later time period.: A= Albacore Tuna, B=Barracuda, BO=Bonito, $M=$ Mackerel, Par $=$

Paralabrax, Seb=Sebastes, $Y=$ Yellowtail, $Y T=$ Yellowfin Tuna 


\section{Relationships with oceanographic conditions}

All eleven species investigated were found to be associated with at least one oceanographic condition (all P and $\mathrm{p}=<0.0001$; Table 4). Abundances of all species tested, with the exception of Mackerel, were correlated with temperature, either contemporaneous temperature or temperature lagged by six months to a year. Abundance of Sebastes was strongly and negatively associated with contemporaneous temperature $\left(\mathrm{R}^{2}=-0.42\right)$, while Albacore was positively associated with contemporaneous temperature $\left(r^{2}=0.22\right)$.

Table 4: CPUE and Oceanographic Conditions

\begin{tabular}{|c|c|c|c|c|c|c|}
\hline $\begin{array}{l}\text { Response } \\
\text { variable }\end{array}$ & $\mathrm{R}^{2}$ & $\mathrm{~F}$ & $\mathrm{n}$ & df & $\begin{array}{l}\text { Independent } \\
\text { variable(s) }\end{array}$ & $\mathrm{r}^{2}$ \\
\hline Albacore & 0.22 & 158.9 & 613 & 1,611 & Temp (contemp.) & -- \\
\hline Barracuda & -0.06 & 38.5 & 607 & 1,605 & Temp (6 month lag) & -- \\
\hline Bonito & 0.17 & 26.7 & 541 & 4,536 & $\begin{array}{c}\text { Current PDO } \\
\text { Temp (6 month lag) } \\
\text { ENSO (5 year lag) } \\
\text { ENSO (6 year lag) }\end{array}$ & $\begin{array}{l}0.14 \\
-0.10 \\
-0.17 \\
-0.05\end{array}$ \\
\hline Dorado & 0.10 & 69.5 & 613 & 1,611 & Temp (contemp.) & -- \\
\hline $\begin{array}{l}\text { Giant } \\
\text { Squid }\end{array}$ & 0.09 & 27.5 & 589 & 2,586 & $\begin{array}{l}\text { Temp (6 month lag) } \\
\text { Temp (2 year lag) }\end{array}$ & $\begin{array}{l}0.03 \\
0.06\end{array}$ \\
\hline Halibut & -0.04 & 26.6 & 613 & 1,611 & Temp (contemp.) & -- \\
\hline Mackerel & 0.20 & 77.9 & 601 & 2,598 & $\begin{array}{c}\text { Current PDO } \\
\text { PDO (1 year lag) }\end{array}$ & $\begin{array}{l}0.15 \\
0.08\end{array}$ \\
\hline Paralabrax & 0.06 & 19.8 & 601 & 2,598 & $\begin{array}{l}\text { Temp (contemp.) } \\
\text { Temp (1 year lag) }\end{array}$ & $\begin{array}{c}0.08 \\
-0.03\end{array}$ \\
\hline Sebastes & -0.42 & 447.7 & 613 & 1,611 & Temp (contemp.) & -- \\
\hline Yellowtail & 0.12 & 82.8 & 613 & 1,611 & Temp (contemp.) & -- \\
\hline Yellowfin & 0.10 & 64.4 & 613 & 1,611 & Temp (contemp.) & -- \\
\hline
\end{tabular}

Table 4: Relationship between CPUE and oceanographic conditions. "Contemp." refers to contemporaneous temperature, or the average temperature during the same month as the CPUE. All P and p values $<0.0001$. 
Dorado, Yellowtail, and Yellowfin were all moderately positively correlated with contemporaneous temperature $\left(\mathrm{r}^{2}=0.10,0.12\right.$, and 0.10 respectively). Barracuda, Halibut, Paralabrax were only weakly negatively associated with temperature $\left(\mathrm{R}^{2}\right.$ $=-0.06,-0.04$, and -0.06 respectively). Two species, Bonito and Mackerel, were weakly positively correlated with PDO values, with Bonito associated with contemporaneous PDO $\left(\mathrm{r}^{2}=0.14\right)$, and Mackerel correlated with both contemporaneous PDO values $\left(\mathrm{r}^{2}=0.15\right)$ and the prior year's PDO values $\left(\mathrm{r}^{2}=\right.$ 0.08). ENSO values from five and six years prior also helped explain the variability in Bonito CPUE values $\left(\mathrm{r}^{2}=-0.17\right.$ and -0.05 , respectively), while no other species was found to be correlated with ENSO.

\section{$\underline{\text { Discussion }}$}

Though total effort of the San Diego commercial passenger fishing vessel (CPFV) fleet did not change markedly during the second half of the twentieth century (this study, CDFW 2001), the landings themselves changed in terms of both catch composition and catch per unit effort of several individual species. Composition of fisheries landings from this fleet changed from being dominated by relatively few species in the 1960 s and 1970 s to a richer, and different, composition in the 1990s and 2010s. There were gradual, cyclic, and (in some cases) rapid shifts in catch composition occurring throughout this period, with major changes from a catch dominated by Barracuda, Yellowtail, Albacore, and Bonito to catch dominated by Paralabrax and Sebastes, with a larger suite of species making up the remainder of catch. 
Several species did not appear until later in the dataset, with Dorado and Yellowtail perhaps explained by the ENSO event of 1982-1983 as both species were associated with warmer waters. That ENSO event, and the warmer water temperatures it brought, has been associated with a potential "faunal shift" in 1983-1984 identified by previous studies (e.g., Miller and McGowan 2013). The current study similarly identified the early 1980 s as a period of change: the early $1980 \mathrm{~s}$ is when the diversity of catch increased (i.e., more species started to appear in the landings data) and octades separated into roughly pre- and post- 1980s associations. One possible driver of this pattern could be increasing sea surface temperatures, whose annual mean rose above the 1919-present long-term mean beginning in the early 1980s (Rasmussen et al. 2019).

Of the 21 focal species investigated, only eight drove the majority of differences in catch composition across the dataset. These species (Albacore Tuna, Barracuda, Bonito, Mackerel, Paralabrax, Sebastes, Yellowtail, Yellowfin Tuna) display various patterns of variability and abundance in the catch data through time (Table 6), with certain species also displaying an association with large-scale oceanographic conditions. For several of the 21 focal species (specifically Yellowtail, Yellowfin Tuna, Dorado, Albacore, Giant Squid), large scale patterns in abundance are difficult to interpret from this dataset. In some cases (e.g., Giant Squid, Dorado), this is due to their appearing very late in the data or in other cases (e.g., Yellowfin Tuna, Albacore) appearing in relatively stable (if variable) catch 
totals (though note that variability of several of these species is associated with large scale oceanographic conditions, as described below).

\section{Species displaying an overall pattern of CPUE decline}

Notably, no species displayed a trend of generally increasing CPUE through time, while CPUE for several species (Bonito, Barracuda, and Mackerel) decreased across the study period. Based on improvements in fishing technologies, a decrease in CPUE of these three species suggests changes in angler preferences, management restrictions, and/or changes in the underlying populations and their distributions.

Changes in large-scale oceanographic conditions did not completely explain the overall decrease in these three species. Bonito was highly cyclical and correlated with both PDO and ENSO values, which are both also cyclical. However, correlations with PDO and ENSO do not explain the directional trend in Bonito because neither PDO nor ENSO values displayed directional long-term trends. Similarly, though Mackerel was positively associated with PDO, that association does not explain the overall directionality of change. Bonito and Barracuda were weakly negatively associated with temperature, which increased slightly during this time, which could potentially explain some of the observed reduction in their CPUE. In the case of Mackerel (which was not found to be associated with temperature), this temperature change does not help explain the reduction in its CPUE. 
It is unclear whether changes in angler preference could explain the observed declines in the relative contribution of these species to the catch totals of the CPFV fleet. Consistent with Mackerel not appearing in the dataset until the early 1970s, Mackerel were not historically a favored target of anglers in California (Young 1969), and the literature does not demonstrate a change in preference for Mackerel through time. Rather, recreational catch of Mackerel has remained a low $(<5 \%)$, but relatively stable, proportion of total landings since at least 1983 (Crone and Hill 2015). While some anecdotal reports suggest a reduction in the popularity of Barracuda in recent decades (Monterey Bay Aquarium 2019), others suggest their popularity remains high (Allen 2014, CA Sea Grant 2021). Finally, in the case of Bonito, the near disappearance of the species from landings data in the early 1990 s is unlikely to be explained by changing preferences, since Bonito are regularly ranked as one of the 15 most sought after species by recreational fishermen in southern California (CDFW 2001).

Changes in CPFV clientele demographics (i.e., race, ethnicity, income level) and concordant differences in seafood preferences (Mintz and DuBois 2002, Moya 2004) may have contributed to shifts in catch composition. While CPFV clientele was overwhelmingly ( $>90 \%)$ composed of well educated, white men with relatively high incomes as of 1990 (Dewees et al. 1990), there are anecdotal reports of changing demographics amongst CPFV anglers, including increased proportions of non-white anglers, since then (T.S. Talley, pers.comm., July 29, 2021). 
In addition to changes in angler preference and the effects of large-scale oceanographic conditions (which do not fully explain CPUE reductions Mackerel, Bonito, and/or Barracuda), changes in management regimes also have the potential to affect landings data and are summarized for each species below:

1. Mackerel: In terms of management, Pacific Mackerel (Scomber japonicus) has had a complex history. Commercial fishing of Mackerel in California intensified in the early part of the twentieth century (c. 1930s), after which harvests underwent long-term decline until reaching record lows in the 1970s (Crone and Hill 2015). At that time, the state implemented a short-lived moratorium on the commercial fishery, which coincided with high CPUE for Mackerel in this study's dataset (c. 1972). From that highpoint, Mackerel CPUE of the CPFV fleet has exhibited a steady decline, with no major changes in management strategies other than the initiation of a harvest control rule of 18,200 metric tons in 2001 for the commercial fishery (PFMC 2011). The decline documented in this study is consistent with declines identified in the commercial fishery, including prior to the initiation of the harvest control rule, as well as recent fisheries-independent stock assessments (Crone et al. 2009, Crone and Hill 2015).

Because neither changing preferences nor large scale oceanographic conditions explain the marked decline in Mackerel CPUE identified by this study, and because this decline is mirrored by and commercial landings and 
stock assessments (Crone et al. 2009, Crone and Hill 2015), it is likely that the decline in CPFV CPUE reflects a true decline in the biomass of this species. However, given the relatively small contribution of recreational fishing to the overall landings of Pacific Mackerel $(<5 \%$ in most years [Crone and Hill 2015]), it is likely that sportfishing catch reflects, rather than significantly contributes to, this decline.

2. Barracuda: In the case of California Barracuda (Sphyraena argentea), changes in management strategies are more likely to explain the significant reduction in CPFV landings that occurred in the late 1960s/early 1970s, after which the species remained relatively depressed, though relatively stable, in catch totals. In the 1930s and 1940s, take of Barracuda by southern California sportfishermen rivaled that of take from the commercial fishery (Pinkas 1966). During the post-World War II boom years, recreational take contributed $70-85 \%$ of total take for this species and by the mid-1960s this species was considered a mainstay of the CPFV fleet (Pinkas 1966). However, fisheries managers in the late 1950s noticed that concerning reductions in Barracuda CPUE in southern California had begun in 1947 and recommended size limits for both the commercial and recreational fisheries. That size limit (28 inches TL), along with a 10 fish bag limit, is still in place today (CDFW 2021). 
Because the main change to Barracuda management coincided with the period of reduction of Barracuda in the CPFV catch documented by this study, it is likely that the reductions in CPFV CPUE of Barracuda are an artifact of that management regime. Importantly, though, the true status of the Barracuda population is poorly known, due to a lack of data and assessment (CDFW 2001).

3. Bonito: The third species to display an overall reduction in CPUE through time in this study is Pacific Bonito (Sarda chiliensis), which, in addition to being highly cyclical, all but disappeared in the CPFV catch beginning in the early 1990s. While significant effort has gone into understanding energetics and morphological characteristics of this species (e.g., Magnuson and Prescott 1966, Ellerby et al. 2000, Sepulveda et al. 2003), relatively little effort has been undertaken to document overall population dynamics and/or stock condition. The limited information available about condition of the California Bonito stock comes from the California Department of Fish and Wildlife (CDFW). Per guidelines established as part of California' Marine Life Management Act of 1998, CDFW completes regular status reports for the major fisheries of the state, beginning with a baseline report in 2001 and followed by updates through 2003, 2006, 2008, and 2011 (CDFW 2013). Though Bonito was included in the 2001 baseline report and the 2008 update, it does not appear in any of the other reports, including the most recent one. 
The baseline report indicated "precipitous" decreases in recreational Bonito landings between 1980-1998, as well as reductions in commercial landings during the second half of the twentieth century. The decline in commercial landings was largely attributed to low market value and restrictions on foreign vessels in Mexican nearshore waters beginning in the early 1980s, where 5090\% of landed Bonito was taken from the period 1943-1958 and 1975-1978 (CDFW 2001). Despite these restrictions, CPFV effort in Mexican waters peaked in 1984-1985 and 1997-1998.

The recreational decline was attributed to a variety of factors, including a shift of the recreational fishery towards more desirable tuna species, changes in distributions due to oceanographic changes, and an overall decline in stock abundance (CDFW 2001). Though CDFW's baseline report did not quantify the relationship between Bonito and large-scale conditions, the current study does not fully support the Department's conclusion. PDO, ENSO, and temperature jointly explain roughly $17 \%$ of the variability in Bonito catch. However, this serves only to explain the strongly cyclical nature of Bonito landings, not the relative absence in CPFV CPUE beginning in 1990 identified here despite periods of warm water conditions that provide favorable conditions for Bonito survival (CDFW 2001). A shift towards more desirable species may explain some of this trend, particularly Yellowtail, Yellowfin Tuna, Dorado, and to some degree Albacore, which were found here to have relatively higher CPUEs in the period 1990-2011 as compared to previous 
years. However, most southern California CPFV fishing trips in U.S. waters have been found not to target any particular species (CDFW 2001). Given this, it is likely that the declines identified by the baseline report and the 2008 update, as well as the near absence of Bonito from post-1990 CPFV landings identified here, are attributable to a reduction in stock abundance.

The last stock assessment for Bonito occurred in 1982, after which a minimum size and weight limit were instituted for both the commercial and recreational fisheries, though up to $50 \%$ of the recreational 10 -fish bag limit can be undersized individuals (CDFW 2021). Given that the majority of change in CPFV CPUE occurred post-1990, an updated stock assessment is highly recommended. While recreational fishing accounts for the majority of take for this species (as opposed to commercial fishing), factors other than fishing pressure (e.g., prey availability) may also account for declines in stock abundance. The relationship between declines in Bonito CPUE should be evaluated against abundance of anchovies, sardines, and other forage fish species targeted by Bonito in southern California. Bonito are currently included in the federal Highly Migratory Species Fishery Management Plan as a "monitored" species (i.e., it is not actively managed on a federal level), and if fisheries-independent data and/or stock assessments support the declines documented here, it may be valuable to consider stronger management of this species. 


\section{Other Trends}

Beside the three species displaying overall declines in CPUE, three additional species/groups displayed trends of note during the period analyzed by this study: Halibut, Sebastes spp, and Paralabrax spp.

1. Halibut: California Halibut (Paralichthys californicus) appeared in relatively high abundance during the first ten years of this data set (1959-1970), experienced a reduction during the following ten years, and has been nearly absent since 1977. Consistent with this, a 2011 stock assessment identified a depleted stock during the whole timeframe modeled (1971-2011), with the 2011 population modeled at only $14 \%$ of the historic spawning biomass (Maunder et al. 2011). Low recruitment was identified as a potential indication that additional management action is necessary to reduce the risk of a fishery collapse, though no specific actions were recommended.

In fact, this species has a long history of management in the state of California, dating back to 1911 when trammel nets were outlawed in state waters (Schultze 2011). Between 1913 and the 1970s, various methods of commercial fishing were intermittently barred either temporally or spatially (Schultze 2011). In 1971, a recreational size limit of 22 inches total length was established along with a five-fish bag limit (Schultze 2011). These limits are still in place today (CDFW 2021), however there has been no evidence for a resulting increase in Halibut population in either the 2011 stock assessment 
or this study. Given their co-incidence, it is likely that the 1971 recreational size limits were the cause of the initial reduction of Halibut CPUE from the San Diego CPFV identified here (beginning in 1971) but not the near-absence of Halibut beginning in 1977.

In addition to fishing pressure, Halibut have historically been impacted negatively by coastal development, which has tended to destroy the coastal bays and estuaries on which juvenile Halibut rely (Fodrie et al. 2009). Heavy dredging and filling of coastal wetlands in the late 1960s may have influenced CPFV landings of the later 1970s, as this species can live up to 30 years and recruits to the fishery at between 4-6 years of age (Haugen 1990). The combination of the limits placed on recreational fishing, as well as the passage of the California Coastal Act and the establishment of the California Coastal Commission (both of which limited continued filling and dredging along the California coast) likely helped to stabilize Halibut populations from further reductions after the late 1970s. However, the fact that CPFV landings have failed to rebound, even to levels seen following the 1971 recreational catch limits, along with the findings of the 2011 stock assessment, suggest it may be worthwhile to revisit commercial regulations and/or stock enhancement strategies. The California Department of Fish and Wildlife and the California Ocean Science Trust are currently developing an updated 2020 Stock Assessment for this species, which will hopefully provide guidance for updated management recommendations. 
Despite their near absence from the CPFV landings in San Diego, Halibut remain popular among the sportfishing community (Zieralski 2009, Hendricks 2014). Because their CPUE has been relatively stable for the past several decades (this study), this may combine with their popularity to create a reduced sense of concern for the status of the stock. For example, the state of California's baseline fishery status report in 2001 stated, "California halibut catches have been remarkably stable over the last two decades" as a contrast to species whose catches have declined. In addition to the impact of shifting baselines on fisheries managers, the effects are also seen in public perception of Halibut, as when relatively high CPUE gets reported in local newspapers as a "comeback" (e.g., Williams 1987), even though the CPUE is still only a very small fraction of historic recreational catch totals (this study). Taken within the historic context (stock assessment, this study), it is clear that Halibut CPUE has stabilized at especially low levels compared to historic baselines, making Halibut an excellent example of shifting baselines' potentially negative effect on conservation and management of natural resources.

2. Sebastes and Paralabrax: The CPUE of both the genera evaluated, Sebastes (rock fishes) and Paralabrax (kelp bass, sand bass), remained relatively stable in the recreational CPUE of the CPFV fleet in San Diego during the period investigated. While analyzing these two groups to genus, rather than species, 
is consistent with previous analyses (Dotson and Charter 2003), this limits what can be interpreted from the apparent stability of these genera in this dataset. Importantly, other studies (e.g., Erisman et al. 2011, Miller and Erisman 2014) have found significant declines in P. clathratus that would not be evident in this study due to this grouping.

Despite strong, clear cyclical patterns in the CPUE of both genera, CPUE of neither group is correlated with the cyclical oceanographic conditions (ENSO and PDO) found to explain a significant portion of variability in catch for several other species analyzed here. This may be surprising given that other studies (e.g., Charter and Sandknop 2000) have found an association between ENSO and larval Sebastes abundance. Again, individual species within Sebastes and/or Paralabrax may in fact be strongly associated with oceanographic conditions (as was identified in species-level analysis that found landing and CPUE reductions through time for several Sebastes species [Jarvis et al. 2004]), but this was not evident at the genus level. Though neither Sebastes nor Paralabrax were correlated with ENSO or PDO in this study, temperature explained a measure of variability in both genera. In the case of Paralabrax, the association is weak, with temperature (contemporaneous and 1 year lag) explaining only $6 \%$ of the variability in catch. By contrast, temperature explains $42 \%$ of the variability in Sebastes, with colder temperatures associated with higher catch totals. This is consistent 
with previous studies (e.g., Jarvis et al. 2004), based on fisheries dependent and fisheries independent data for specific rock fish species.

The association of Sebastes species with cold water has long been documented in scientific literature (e.g., Ainley et al. 1993, Laidig et al. 2007), though mostly from the perspective of larvae abundance and juvenile recruitment. Given this strong and well-documented association between Sebastes and cold water, it may be prudent to model expected responses of this genus to changing ocean temperatures associated with global climate change, and with consideration of the recently documented links between MPAs and increases in the larvae of several rockfishes historically targeted for fishing (Thompson et al. 2017). Given the strongly cyclical nature of the CPUE for these species, and considering the susceptibility of larvae to temperature, management strategies may also be worth investigating to see if an adaptive model based on current ecosystem or stock conditions would be more appropriate than the currently fixed catch limits in place today. However, given that this study only analyzed these groups to the genus level, and because management can differ greatly from species to species, further investigation into more specific patterns of abundance would be valuable.

In the case of Paralabrax, the apparent stability of CPUE identified by this study should be considered within the context of other reports documenting a decline in at least one Paralabrax species (P. clathratus) (Thompson et al. 
2017), as well as recent studies documenting "hyperstability" of the two Paralabrax species targeted by the CPFV fishery in San Diego. Hyperstability, a process by which CPUE can remain high even while a species experiences decline in true abundance, has been documented as being particularly prevalent in nearshore coastal species whose life history involves regular, predictable spawning aggregations including Paralabrax nebulifer and P. clathratus (Erisman et al. 2011).

\section{Importance of Oceanographic Variables}

Of the eleven species investigated for a relationship with oceanographic conditions, all were found to be associated with at least one of the three large scale oceanographic conditions examined here (temperature, PDO, and ENSO). For several of these species, this was despite no overall trend in abundance in the CPFV landings. In nearly all cases, contemporaneous or recent past temperature explained the most variability (with the exception of Bonito and Mackerel, whose associations with PDO and ENSO were discussed previously). In the cases of Barracuda, Halibut, and Paralabrax, the association was fairly weak, with temperature explaining between $4-6 \%$ of the variability. In these cases, it is likely that another variable (e.g., availability of prey items) is responding strongly to temperature, which then affects the target species. For other species, though, temperature explains a relatively large percentage of variability in CPUE upwards of $42 \%$ for Sebastes, $22 \%$ for Albacore, $17 \%$ for Bonito, and around $10 \%$ for Dorado, Giant Squid, Yellowtail, and Yellowfin tuna. For all but one of 
these species (Sebastes), temperature is associated with an increase in CPUE. However, it is unlikely that contemporaneous temperature (or even a 6-month lagged temperature) is directly affecting the underlying populations. Instead, temperature is likely affecting their range, with warmer water bringing migratory species like tunas farther north and increasing their availability to the San Diego CPFV fleet. While this is not news to the fishing community, documenting this type of association within the context of changing ocean waters can be informative for natural resource managers. As species' ranges change with rising sea surface temperatures, it will become increasingly important to avoid overfishing in the face of local abundance despite potentially overall declining stocks (Chavez et al. 2017).

\section{Conclusions}

Efforts to protect and manage coastal marine resources of California will be both more effective and more cost-efficient when based on the best available information regarding focal populations and habitats. As this study has shown, analysis of CPFV landings can provide an important tool to help understand what is happening in the populations of popular sportfishing species. In some cases, such as California Halibut, this analysis can help underscore previously identified patterns and provide additional support for necessary management actions in recreational and/or commercial fishing. In other cases, such as Bonito, these analyses highlight patterns of decline that have so far not instigated active management. Such analyses also support the use of quantitative, non-traditional 
data sets in investigating ecological patterns, particularly in cases where minimizing the effects of shifting baselines can improve restoration targets.

However, data gaps exist for interpreting causes of identified patterns (e.g., social data on angler demographics and preferences) and opportunities exist for better understanding the impact of management actions on target species (e.g., collaborative fisheries programs to collect data regarding catch sizes, locations, timing, bycatch, etc.). While it is important to combine fisheries dependent historical analyses with fisheries-independent investigations to fully understand the population dynamics of particular species of interest, this study helps tease out some of the longer-term trends not always available through the use of modern scientific data alone. 


\section{References}

1. Ainley, D. G., Sydeman, W. J., Parrish, R. H., \& Lenarz, W. H. (1993). Oceanic factors influencing distribution of young rockfish (Sebastes) in central California: a predator's perspective. California Cooperative Oceanic Fisheries Investigations Reports, 34, 133-139.

2. Allen, L. (2014). Sportfish Profiles: California Barracuda (Sphyraena argentea). California State University, Northridge. Nearshore Marine Fisheries Research Program. Available at: $\mathrm{http}: / /$ www.csun.edu/ nmfrp/californiabarracuda.html

3. Arlinghaus, R., \& Cooke, S. J. (2009). Recreational fisheries: socioeconomic importance, conservation issues and management challenges. Recreational hunting, conservation and rural livelihoods: science and practice, 39-58.

4. Bellquist, L. F., Graham, J. B., Barker, A., Ho, J., \& Semmens, B. X. (2016). Long-term dynamics in "trophy" sizes of pelagic and coastal pelagic fishes among California recreational fisheries (1966-2013). Transactions of the American Fisheries Society, 145(5), 977-989.

5. Bellquist, L., Beyer, S., Arrington, M., Maeding, J., Siddall, A., Fischer, P., ... \& Wegner, N. C. (2019). Effectiveness of descending devices to mitigate the effects of barotrauma among rockfishes (Sebastes spp.) in California recreational fisheries. Fisheries Research, 215, 44-52.

6. Bestor, T.C., (2000). How sushi went global. Foreign Policy, (121), p.54.

7. Bishop, J. (2006). Standardizing fishery-dependent catch and effort data in complex fisheries with technology change. Reviews in Fish Biology and Fisheries, 16(1), 21-38.

8. Bruland, K. W., Bertine, K., Koide, M., \& Goldberg, E. D. (1974). History of metal pollution in southern California coastal zone. Environmental Science \& Technology, 8(5), 425-432.

9. Burden, T., (2019). "Fishfinder Technology Explained." Retrieved from: https://www.westmarine.com/WestAdvisor/Selecting-a-Fishfinder

10. Burger, J., \& Gochfeld, M. (2009). Perceptions of the risks and benefits of fish consumption: Individual choices to reduce risk and increase health benefits. Environmental research, 109(3), 343-349.

11. Butler, J. L., Jacobson, L. D., Barnes, J. T., Moser, H. G., \& Collins, R. (1999). Stock assessment of cowcod. Appendix to Status of the Pacific Coast Groundfish Fishery Through 1998 and Recommended Acceptable Biological Catches for 1999 (SAFE Report).

12. CA Sea Grant. (2021). "California Seafood Profiles: California Barracuda, Sphyraena argentea". Available at: https://caseagrant.ucsd.edu/seafood-profiles/california-barracuda

13. Carroll, L. (2016). "Eating fish 2-3 times a week is recommended: What about every day?" Today: Health and Wellness. http://www.today.com/health/it-ok-eat-fish-every-day-t34261 (August 26, 2016)

14. CDFW (2001). "California's Living Marine Resources: A status report." California Department of Fish and Wildlife. Publication SG01-11. Editors W. Leet, C. Dewees, R. Klingbeil, E. Larson

15. CDFW (2013). Status of the fisheries report: an update through 2011. Report the California Fish and Game Commission as directed by the Marine Life Management Act of 1998.

16. CDFW (2021). "California Ocean Sportfishing Regulations", California Department of Fish and Wildlife Annual Sportfishing Booklet, Sacramento, CA. Available at: https://wildlife.ca.gov/Fishing/Ocean/Regulations/Sport-Fishing

17. Charter, S. R., \& Sandknop, E. M. (2000). Abundance and distribution of rockfish (Sebastes) larvae in the Southern California Bight in relation to environmental conditions and fishery exploitation. Calif. Coop. Oceanic Fish. Invest. Rep, 41, 132-147.

18. Chavez, F. P, Costello, C., Aseltine-Neilson, D., Doremus, D., Field, J. C, Gaines, S. D, et al. (2017). Readying California Fisheries for Climate Change. UC San Diego: California Sea Grant College Program. Retrieved from https://escholarship.org/uc/item/2kr7839k

19. Clarke, K. R. (1993). Non-parametric multivariate analyses of changes in community structure. Australian journal of ecology, 18(1), 117-143. 
20. Coleman, F. C., Figueira, W. F., Ueland, J. S., \& Crowder, L. B. (2004). The impact of United States recreational fisheries on marine fish populations. Science, 305(5692), 19581960.

21. Cooke, S. J., \& Cowx, I. G. (2004). The role of recreational fishing in global fish crises. BioScience, 54(9), 857-859.

22. Cowx, I. G. (2002). Recreational fishing. Handbook of fish biology and fisheries. Volume 2: Fisheries, 367-390.

23. Crone, P. R., Hill, K. T., McDaniel, J. D., \& Lynn, K. (2011). Pacific mackerel (Scomber japonicus) stock assessment for USA management in the 2011-12 fishing year. Pacific Fishery Management Council, 7700.

24. Crone, P. R., \& Hill, K. T. (2015). Pacific mackerel (Scomber japonicus) stock assessment for USA management in the 2015-16 fishing year. Pacific Fishery Management Council, 7700, 131.

25. Crooke, S. J. (1992). History of giant sea bass fishery. California's Marine Resources and their Utilization.(Leet, WS, Dewees, CM, Klingbeil, R., and Larson, E., eds.) University of California Sea Grant extension publication (UCSGEP-92-12), Davis, California, 153-157.

26. Dayton, P. K., Tegner, M. J., Edwards, P. B., \& Riser, K. L. (1998). Sliding baselines, ghosts, and reduced expectations in kelp forest communities. Ecological Applications, 8(2), 309-322.

27. Dewees, C. M., Strange, E. M., \& Guagnano, G. (1990). Competing for the recreational dollar: an analysis of the California commercial passenger-carrying fishing vessel industry. Marine Fisheries Review, 52(1), 1-6.

28. Dotson, R., \& Charter, R. (2003). Trends in the southern California sport fishery. California Cooperative Oceanic Fisheries Investigations Report, 94-106.

29. Edwards, S. F. (1992). Evidence of structural change in preferences for seafood. Marine Resource Economics, 7(3), 141-151.

30. Ellerby, D. J., Altringham, J. D., Williams, T., \& Block, B. A. (2000). Slow muscle function of Pacific bonito (Sarda chiliensis) during steady swimming. Journal of Experimental Biology, 203(13), 2001-2013.

31. Erisman, B. E., Allen, L. G., Claisse, J. T., Pondella, D. J., Miller, E. F., \& Murray, J. H. (2011). The illusion of plenty: hyperstability masks collapses in two recreational fisheries that target fish spawning aggregations. Canadian Journal of Fisheries and Aquatic Sciences, 68(10), 1705-1716.

32. Felando, A., \& Medina, H. (2012). The origins of California's high-seas tuna fleet. Journal of San Diego History, 58(1/2), 1-40.

33. Fodrie, F. J., Levin, L. A., \& Lucas, A. J. (2009). Use of population fitness to evaluate the nursery function of juvenile habitats. Marine Ecology Progress Series, 385, 39-49.

34. Fortibuoni, T., Libralato, S., Arneri, E., Giovanardi, O., Solidoro, C., \& Raicevich, S. (2017). Fish and fishery historical data since the 19th century in the Adriatic Sea, Mediterranean. Scientific data, 4(1), 1-13.

35. Great Britain; Royal Commission on Trawling. (1885). "Report of the Commissioners appointed to inquire and report upon the complaints that have been made by line and drift net fishermen of injuries sustained by them in their calling owing to the use of the trawl net and beam trawl in the territorial waters of the United Kingdom". Eyre and Spottiswoode, London.

36. Gribble, N.A. (2003) GBR-prawn: modelling ecosystem impacts of changes in fisheries management of the commercial prawn (shrimp) trawl fishery in the far northern Great Barrier Reef. Fisheries Research 65, 493-506.

37. Gruber, N., Hauri, C., Lachkar, Z., Loher, D., Frölicher, T. L., \& Plattner, G. K. (2012). Rapid progression of ocean acidification in the California Current System. science, 337(6091), 220-223.

38. Halpern, B.S., S. Walbridge, K.A. Selkoe, C.V. Kappel, F. Micheli, C. D’Agrosa, ... R. Fujita. (2003). A Global Map of Human Impact on Marine Ecosystems. Proceedings of the National Academy of Sciences USA, 100, 892.

39. Haugen, C.W. ed., (1990). The California Halibut, Paralichthys Californicus, Resources and Fisheries. State of California, Resources Agency, Department of Fish and Game. 
40. Heberer, C., Aalbers, S. A., Bernal, D., Kohin, S., DiFiore, B., \& Sepulveda, C. A. (2010). Insights into catch-and-release survivorship and stress-induced blood biochemistry of common thresher sharks (Alopias vulpinus) captured in the southern California recreational fishery. Fisheries Research, 106(3), 495-500.

41. Hendricks, J. "How to Catch California Halibut: Bounce-ball trolling proves highly effective for big California halibut.” Saltwater Sportsman. June 2014. Web. Accessed 11 December 2017.

42. Hilborn, R., \& Ovando, D. (2014). Reflections on the success of traditional fisheries management. ICES Journal of Marine Science, 71(5), 1040-1046.

43. Holts, D. (1985). Recreational albacore, Thunnus alalunga, fishery by US West Coast commercial passenger fishing vessels. Marine Fisheries Review, 47(3), 48-53.

44. Huang, B., V.F. Banzon, E. Freeman, J. Lawrimore, W. Liu, T.C. Peterson, T.M. Smith, P.W. Thorne, S.D. Woodruff, and H.-M. Zhang, (2014). Extended Reconstructed Sea Surface Temperature version 4 (ERSST.v4): Part I. Upgrades and intercomparisons. Journal of Climate, 28, 911-930, doi:10.1175/JCLI-D-14-00006.1

45. Jackson, J. B. (1997). Reefs since columbus. Coral reefs, 16(1), S23-S32.

46. Jackson, J. B. (2001). What was natural in the coastal oceans?. Proceedings of the National Academy of Sciences, 98(10), 5411-5418.

47. Jackson, J. B., Kirby, M. X., Berger, W. H., Bjorndal, K. A., Botsford, L. W., Bourque, B. J., ... \& Warner, R. R. (2001). Historical overfishing and the recent collapse of coastal ecosystems. science, 293(5530), 629-637.

48. Jarvis, E. T., Allen, M. J., \& Smith, R. W. (2004). Comparison of recreational fish catch trends to environment-species relationships and fishery-independent data in the southern California bight, 1980-2000. California Cooperative Oceanic Fisheries Investigations Report, 45, 167.

49. Jarvis, E. T., \& Lowe, C. G. (2008). The effects of barotrauma on the catch-and-release survival of southern California nearshore and shelf rockfish (Scorpaenidae, Sebastes spp.). Canadian Journal of Fisheries and Aquatic Sciences, 65(7), 1286-1296.

50. Kirlin, J., Caldwell, M., Gleason, M., Weber, M., Ugoretz, J., Fox, E., \& Miller-Henson, M. (2013). California's Marine Life Protection Act Initiative: supporting implementation of legislation establishing a statewide network of marine protected areas. Ocean \& Coastal Management, 74, 3-13.

51. Laidig, T. E., Chess, J. R., \& Howard, D. F. (2007). Relationship between abundance of juvenile rockfishes (Sebastes spp.) and environmental variables documented off northern California and potential mechanisms for the covariation. Fishery Bulletin, 105(1), 39-49.

52. Lane, R. K. (1965). Wind, nearshore ocean temperature, and the albacore tuna catch off Oregon. FISH Commission of Oregon.

53. Leschin-Hoar, C. (2014). "Sustainable seafood dives into the mainstream." Future Food 2050. (August 20, 2014). https://futurefood2050.com/sustainable-seafood-dives-into-themainstream/

54. Limbaugh, C., (1955). Fish life in the kelp beds and the effects of kelp harvesting. UC San Diego: Scripps Institution of Oceanography.

55. Magnuson, J. J., \& Prescott, J. H. (1966). Courtship, locomotion, feeding, and miscellaneous behaviour of Pacific bonito (Sarda chiliensis). Animal behaviour, 14(1), 5467.

56. Martinez-Abrain, A., Maestre, R. and Oro, D. (2002) Demersal trawling waste as a food source for Western Mediterranean seabirds during the summer. ICES Journal of Marine Science 59, 529-537.

57. Maunder, M., Reilly, P., Tanaka, T., Schmidt, G. and Penttila, K., (2011). California halibut stock assessment. California Department of Fish and Game.

58. McClenachan, L. (2009). Documenting Loss of Large Trophy Fish from the Florida Keys with Historical Photographs. Conservation Biology. 23(3):636-643.

59. McPhee, D. P., Leadbitter, D., \& Skilleter, G. A. (2002). Swallowing the bait: is recreational fishing in Australia ecologically sustainable?. Pacific conservation biology, $8(1), 40-51$. 
60. Millard, M. J., Welsh, S. A., Fletcher, J. W., Mohler, J., Kahnle, A., \& Hattala, K. (2003). Mortality associated with catch and release of striped bass in the Hudson River. Fisheries Management and Ecology, 10(5), 295-300.

61. Miller, E. F., \& McGowan, J. A. (2013). Faunal shift in southern California's coastal fishes: A new assemblage and trophic structure takes hold. Estuarine, Coastal and Shelf Science, 127, 29-36.

62. Miller, E. F., \& Erisman, B. (2014). Long-term trends of southern California's kelp and barred sand bass populations: a fishery-independent assessment. California Cooperative Oceanic Fisheries Investigations Reports, 55, 119-127.

63. Mintz, S. W., \& Du Bois, C. M. (2002). The anthropology of food and eating. Annual review of anthropology, 31(1), 99-119.

64. Monterey Bay Aquarium (2019). "California Barracuda". Retrieved from https:/www.montereybayaquarium.org/animals-and-exhibits/animalguide/fishes/california-barracuda

65. Moya, J., (2004). Overview of fish consumption rates in the United States. Human and Ecological Risk Assessment, 10(6), pp.1195-1211.

66. Myers, R. A., \& Worm, B. (2003). Rapid worldwide depletion of predatory fish communities. Nature, 423(6937), 280-283.

67. Olsen, R. (2002) "Slow Motion Disaster: Below the Waves". Los Angeles Times. November 17, 2002.

68. Palmer, R., (1912). California Tuna Canning Industry. Pacific Fisherman Year Book, pp.76-77. "Fisheries Enjoy Prosperous Year," San Diego Union, January 1, 1912

69. Parker, S. J., McElderry, H. I., Rankin, P. S., \& Hannah, R. W. (2006). Buoyancy regulation and barotrauma in two species of nearshore rockfish. Transactions of the American Fisheries Society, 135(5), 1213-1223.

70. Parnell, P. E., Dayton, P. K., Fisher, R. A., Loarie, C. C., \& Darrow, R. D. (2010). Spatial patterns of fishing effort off San Diego: implications for zonal management and ecosystem function. Ecological Applications, 20(8), 2203-2222.

71. Pauly, D. (1995). Anecdotes and the shifting baseline syndrome of fisheries. Trends in Ecology and Evolution. 10(10):430.

72. Pauly, D., Christensen, V., Dalsgaard, J., Froese, R., \& Torres, F. (1998). Fishing down marine food webs. Science, 279(5352), 860-863.

73. Pauly, D., Hilborn, R. and Branch, T.A., (2013). Fisheries: does catch reflect abundance?. Nature, 494(7437), p.303.

74. Pauly, D., \& Zeller, D. (2016). Catch reconstructions reveal that global marine fisheries catches are higher than reported and declining. Nature communications, 7(1), 1-9.

75. Perry, A. L., Low, P. J., Ellis, J. R., \& Reynolds, J. D. (2005). Climate change and distribution shifts in marine fishes. science, 308(5730), 1912-1915.

76. PFMC (2011). Coastal Pelagic Species Fishery Management Plan as Amended through Amendment 13.

77. Pinkas, L. (1966). Fish Bulletin 134. Management Study of The California Barracuda Sphyraena argentea Girard.

78. Pitcher T.J. (2001). Fisheries managed to rebuild ecosystems? Reconstructing the past to salvage the future. Ecological Applicationa. 11:601-607.

79. Pollnac, R. B., \& Poggie, J. J. (2008). Happiness, well-being and psychocultural adaptation to the stresses associated with marine fishing. Human Ecology Review, 194-200.

80. Pribyl, A. L., Schreck, C. B., Kent, M. L., Kelley, K. M., \& Parker, S. J. (2012). Recovery potential of black rockfish, Sebastes melanops Girard, recompressed following barotrauma. Journal of Fish Diseases, 35(4), 275-286.

81. R Core Team. R: A language and environment for statistical computing. R Foundation for Statistical Computing, Vienna, Austria. 2013.

82. Rankin, P. S., Hannah, R. W., Blume, M. T., Miller-Morgan, T. J., \& Heidel, J. R. (2017). Delayed effects of capture-induced barotrauma on physical condition and behavioral competency of recompressed yelloweye rockfish, Sebastes ruberrimus. Fisheries Research, 186, 258-268. 
83. Rasmussen, L. L., Carter, M. L., Flick, R. E., Hilbern, M., Fumo, J. T., Cornuelle, B. D., ... \& McGowan, J. A. (2020). A century of Southern California coastal ocean temperature measurements. Journal of Geophysical Research: Oceans, 125(5), e2019JC015673.

84. Sáenz-Arroyo, A., Roberts, C. M., Torre, J., \& Cariño-Olvera, M. (2005). Using fishers' anecdotes, naturalists' observations and grey literature to reassess marine species at risk: the case of the Gulf grouper in the Gulf of California, Mexico. Fish and Fisheries, 6(2), 121-133.

85. Sala, E., Aburto-Oropeza, O., Reza, M., Paredes, G., \& López-Lemus, L. G. (2004). Fishing down coastal food webs in the Gulf of California. Fisheries, 29(3), 19-25.

86. Santora, J. A., Hazen, E. L., Schroeder, I. D., Bograd, S. J., Sakuma, K. M., \& Field, J. C. (2017). Impacts of ocean climate variability on biodiversity of pelagic forage species in an upwelling ecosystem. Marine Ecology Progress Series, 580, 205-220.

87. Schroeder, D. M., \& Love, M. S. (2002). Recreational fishing and marine fish populations in California. California Cooperative Oceanic Fisheries Investigations Report, 182-190.

88. Schultze, D., Wild, P., Wertz, S., Tanaka, T., Vincent, A., (2011). California halibut stock assessment: Appendix A "Significant milestones in California halibut fishery management". California Department of Fish and Game.

89. Sepulveda, C. A., Dickson, K. A., \& Graham, J. B. (2003). Swimming performance studies on the eastern Pacific bonito Sarda chiliensis, a close relative of the tunas (family Scombridae) I. Energetics. Journal of Experimental Biology, 206(16), 2739-2748.

90. Southwick and Associates, Inc.. "Economic Contributions of Recreational Fishing: U.S. Congressional Districts", prepared for the American Sportfishing Association, Feb 2017.

91. Southwick and Associates, Inc.. "The Potential Economic and Conservation Impacts of Proposed Marine Recreational Fishing Closures in Southern California", prepared for the American Sportfishing Association, October 15, 2009.

92. Squire Jr, J.L., (1983). Warm water and southern California recreational fishing: A brief review and prospects for 1983. Mar. Fish. Rev, 45(4-6), pp.27-34.

93. Tegner, M. J., \& Dayton, P. K. (2000). Ecosystem effects of fishing in kelp forest communities. ICES Journal of Marine Science, 57(3), 579-589.

94. Thompson, A. R., Chen, D. C., Guo, L. W., Hyde, J. R., \& Watson, W. (2017). Larval abundances of rockfishes that were historically targeted by fishing increased over 16 years in association with a large marine protected area. Royal Society open science, 4(9), 170639.

95. Valero, J., \& Waterhouse, L. California White Seabass Stock Assessment in 2016 [Internet]. Center for the Advancement of Population Assessment Methodology, Scripps Institution of Oceanography. Available from: www. capamresearch. org/sites/default/files/WSB_SA_Report_2016. pdf [Accessed: Dec 11, 2017].

96. van Denderen, P. D., van Kooten, T., \& Rijnsdorp, A. D. (2013). When does fishing lead to more fish? Community consequences of bottom trawl fisheries in demersal food webs. Proceedings of the Royal Society B: Biological Sciences, 280(1769), 20131883.

97. Williams, R. "Sea bass, halibut better, but why?" San Diego Union Tribune. June 7, 1987. Web. Accessed 22 December 2017.

98. Worm, B., Barbier, E. B., Beaumont, N., Duffy, J. E., Folke, C., Halpern, B. S., ... \& Watson, R. (2006). Impacts of biodiversity loss on ocean ecosystem services. science, 314(5800), 787-790.

99. Yoklavich, M. M., Love, M. S., \& Forney, K. A. (2007). A fishery-independent assessment of an overfished rockfish stock, cowcod (Sebastes levis), using direct observations from an occupied submersible. Canadian Journal of Fish \& Aquatic Sciences, 64(12), 1795-1804.

100. Young, P.H., (1969). Fish Bulletin 145. The California Partyboat Fishery 19471967. Scripps Institution of Oceanography Library.

101. Zedler, J.B., (1991). The challenge of protecting endangered species habitat along the southern California coast. Coastal Management, 19(1), pp.35-53.

102. Zhou, S. (2008). Fishery by-catch and discards: a positive perspective from ecosystem-based fishery management. Fish and Fisheries, 9(3), 308-315.

103. Zieralski, E. "Incredible run of halibut angling is no fish tale." San Diego Union Tribune. June 2009. Web. Accessed 11 December 2017. 


\section{Appendix A: Catch and CPUE for all 21 focal species}

Total annual catch (orange line, right axis) and CPUE (grey bars, left axis) 1959-2011. Note CPUE is log+1 transformed and catch is presented in the thousands.
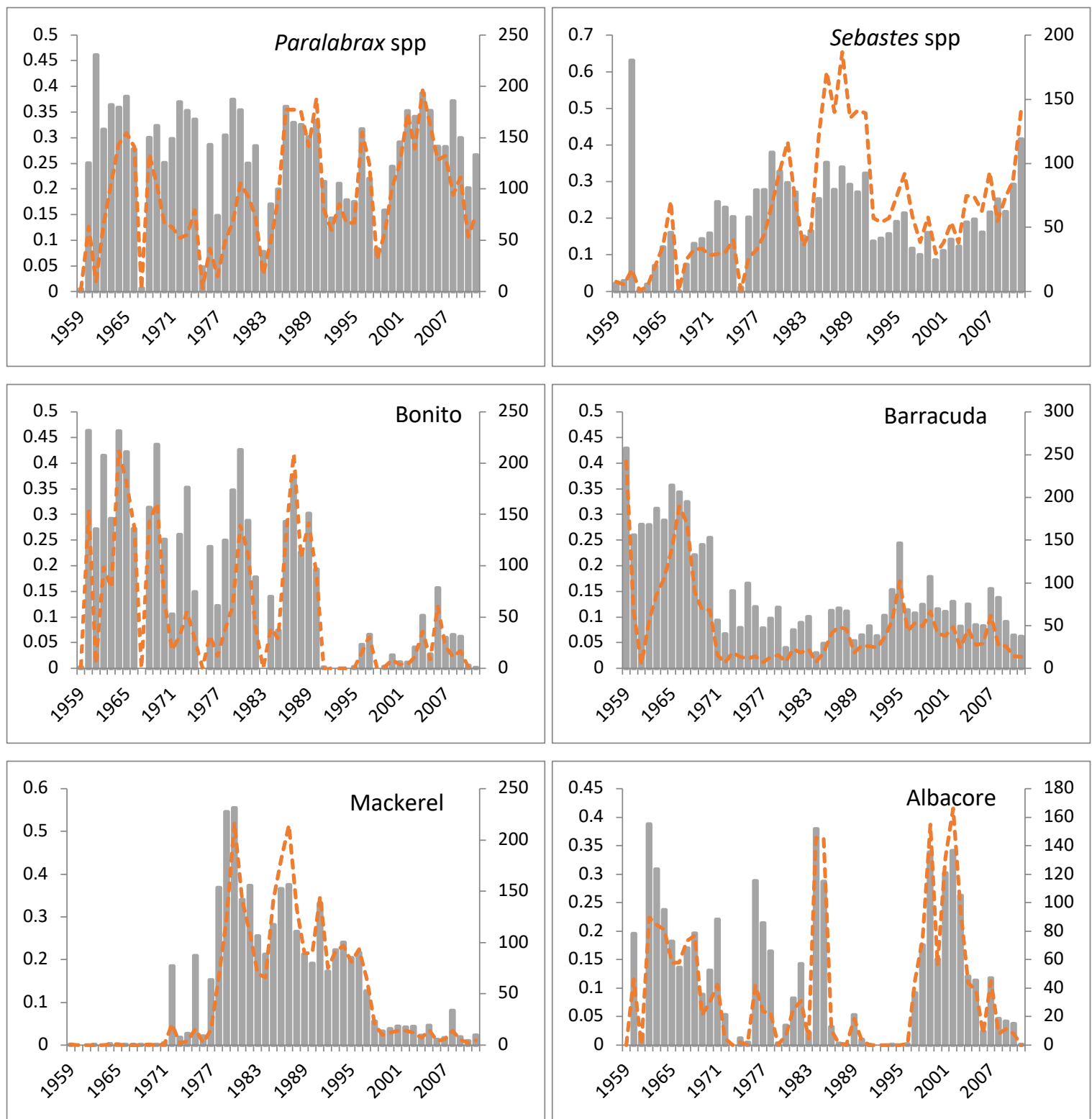

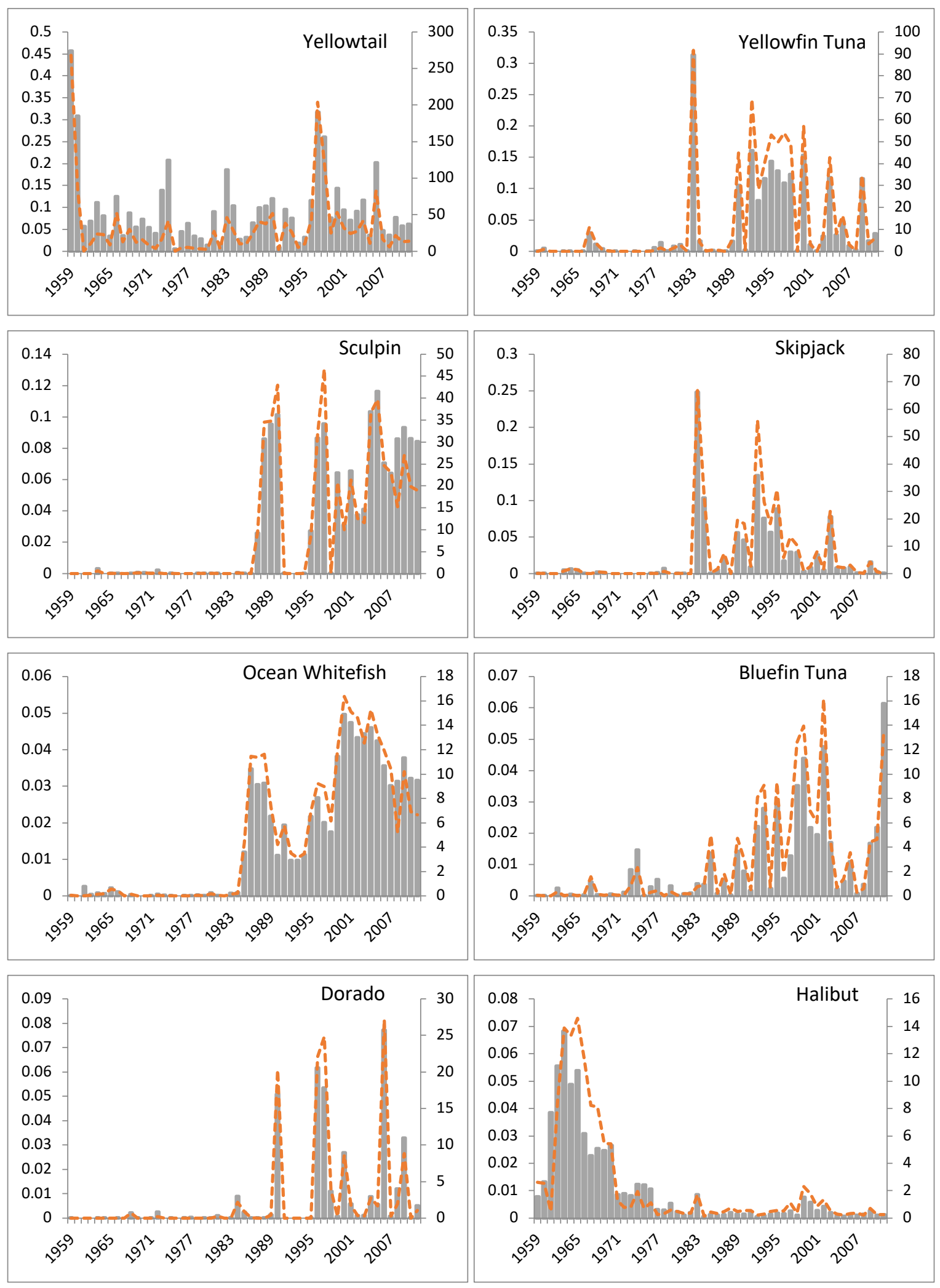

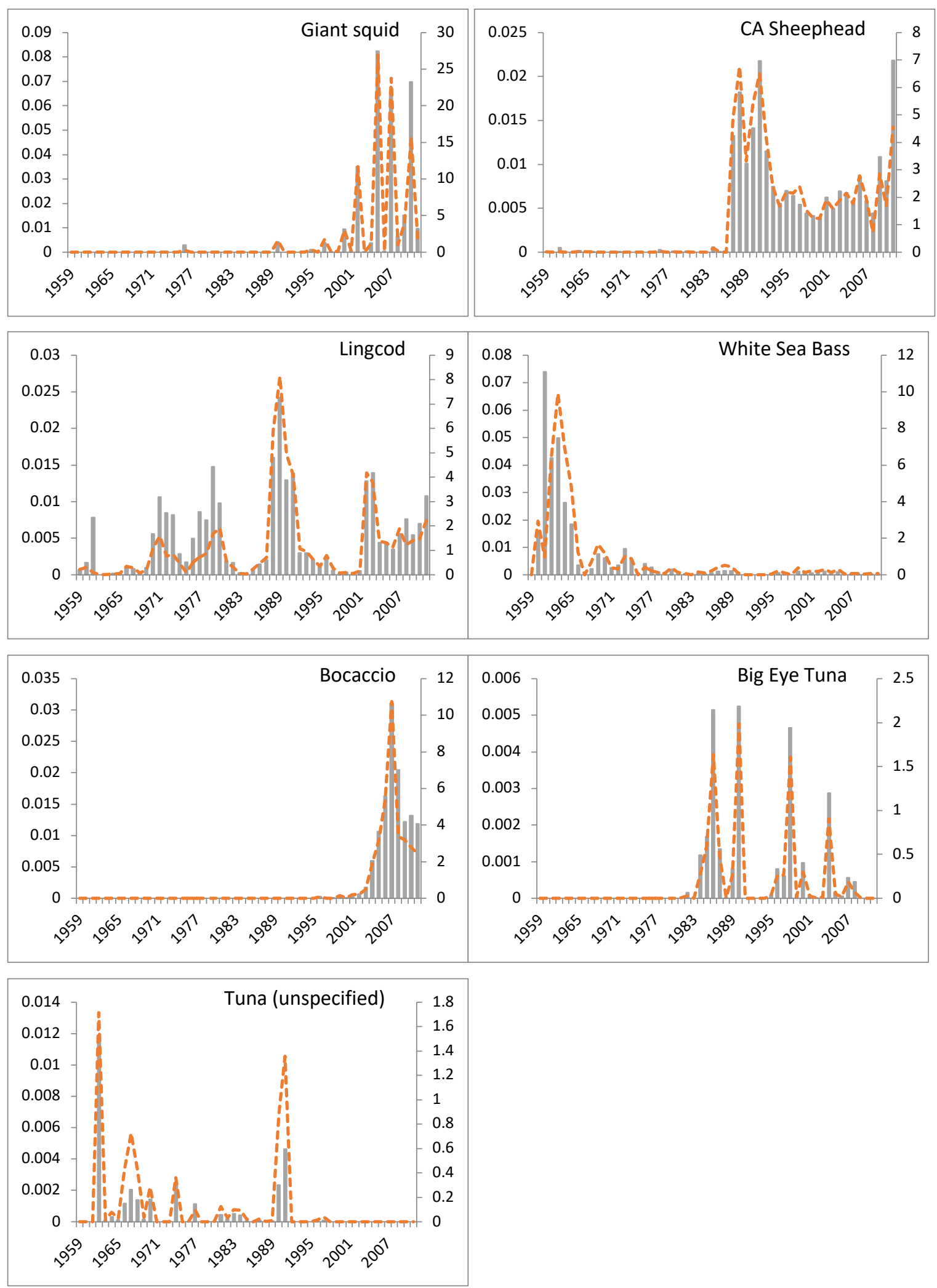